Buca Eğitim Fakültesi Dergisi,

2021, Say1 51, s.403-432

Araştırma Makalesi
The Journal of Buca Faculty of

Education, 2021, Issue 51, p.403-432

Original Research

\title{
Matematik Öğretmeni Adaylarının Bilgisayar Destekli Ortamda Geometri Problem Çözme Stratejilerinin Belirlenmesi*
}

\section{Identifying of Problem Solving Strategies of Pre-Service Mathematics Teachers in a Computer-Aided Environment}

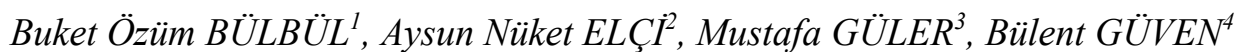

\begin{abstract}
${ }^{1}$ Sorumlu Yazar, Dr. Öğr. Üyesi, Matematik ve Fen Bilimleri Ĕgitimi Bölümü, Eğitim Fakültesi, Manisa Celal Bayar Üniversitesi, Türkiye, buket.bulbul@cbu.edu.tr, (https://orcid.org/00000001-9610-7053)

${ }^{2}$ Dr. Öğr. Üyesi, Matematik ve Fen Bilimleri Ĕ̆itimi Bölümü, Eğitim Fakültesi, Manisa Celal Bayar Üniversitesi,Türkiye, aysunnuketelci@hotmail.com, (https://orcid.org/0000-0002-0200$668 X)$

${ }^{3}$ Arş. Gör. Dr., Matematik ve Fen Bilimleri Eğitimi Bölümü, Fatih Eğitim Fakültesi, Trabzon Üniversitesi, Türkiye, mustafaguler@trabzon.edu.tr, (https://orcid.org/0000-0002-4082-7585)

${ }^{4}$ Prof. Dr., Matematik ve Fen Bilimleri Eğitimi Bölümü, Fatih Eğitim Fakültesi, Trabzon

Üniversitesi,Türkiye,bguven@trabzon.edu.tr,(https://orcid.org/0000-0001-8767-6051)
\end{abstract}

Geliş Tarihi:10.03.2021

Kabul Tarihi:13.06.2021

ÖZ

$\mathrm{Bu}$ çalışmada matematik öğretmeni adaylarının bilgisayar destekli ortamda geometri problem çözme stratejilerinin belirlenmesi amaçlanmıştır. Özel durum çalışması yönteminin kullanıldığı bu çalışma, 2020-2021 Eğitim Öğretim yılında bir devlet üniversitesinin ikinci sınıfında öğrenim gören 14 matematik öğretmeni adayı ile yürütülmüştür. Microsoft Teams programı aracıllğıyla bir dönem boyunca çevrimiçi öğrenme ortamında öğretmen adaylarına tasarlanan 15 farklı rutin olmayan problemler sunulmuştur. Çalışmanın verileri, araştırmacılar tarafından geliştirilen etkinlikler, uygulama sonrasında araştırmacılar tarafından geliştirilen ve 10 tane rutin olmayan problemlerden oluşan problem çözme başarı testi, klinik mülakatlar ve araştırmacıların süreç içerisinde tuttuğu alan notlarından elde edilmiştir. Çalışmanın sonucunda bilgisayar yazılımı desteğiyle hazırlanmış geometri problemlerini çözmeye yönelik stratejiler; görselleştirme, döndürme, iliş̧ilendirme, tahmin etme, farkll durumları düşünme, ek çizim yapma, sürükleme, uç durumları düşünme, doğrulama, tablolaştırma olarak belirlenmiştir. Çalışmanın sonuçlarından hareketle benzer tasarımlar için çalışmada elde edilen bu becerileri merkeze alan öğrenme ortamlarının hazırlanabileceği ve eğitimsel sonuçların irdelenebileceği çalışmanın önerileri arasında yer almaktadir.

Anahtar Kelimeler: Problem çözme stratejileri, problem çözme, bilgisayar destekli geometri, geometri eğitimi.

\begin{abstract}
This study aims to determine on problem solving strategies of pre-service mathematics teachers in a computer aided environment. This study, in which the case study method was used, was carried out with

\footnotetext{
* Bu çalışma Manisa Celal Bayar Üniversitesi Bilimsel Araştırma Projeleri Koordinatörlügü tarafından desteklenen BAP 2020-020 kodlu ve "Matematik Öğretmeni Adaylarının Problem Çözme Becerilerine Yönelik Bilgisayar Destekli Geometri Etkinliklerinin Geliştirilmesi, Uygulanması ve Değerlendirilmesi” başlıklı projeden üretilmiştir.
} 
14 pre-service mathematics teachers studying at a state university in the 2020-2021 academic year. Through the Microsoft Teams platform, 15 different non-routine problems designed for pre-service teachers have been implemented in an online learning environment during a semester. The data of the study were obtained from 10 geometry problems developed by the researchers and applied after the application, clinical interviews and the field notes of the researcher. As a result of the study, the strategies for solving geometry problems prepared with the support of computer software were determined as visualization, rotation, association, estimation, looking at different situations, additional drawing, dragging, thinking extreme cases, proving, picturing. Based on the results of the study, it is among the recommendations of the study that the educational results can be examined by working with students at different levels with the pre-test-post-test control and experimental groups for similar designs.

Keywords: Problem-solving strategies, problem-solving, computer-assisted geometry, geometry education.

\section{GíRİş}

Genelde matematik özelde ise geometri, öğrenciler tarafindan anlaşılması zor bir ders olarak görülebilmektedir (Bulut, Ekici, İșeri ve Helvac1, 2002). Bu durumun temel sebeplerinden biri öğrencilere okul ortamlarında birtakım formüllerin ezberletilerek şekil üzerine aktarılmaya çalışılması olarak gösterilebilir. Söz konusu bu anlaşılmazlık geometri derslerinin problem çözmeyi merkeze alan içerikler oluşturularak sürdürülmesi ile giderilebilir (Milli Eğitim Bakanlığı [MEB], 2018; National Council of Teachers of Mathematics [NCTM], 2000).

Genel anlamda problem çözme bireylerin karşılaştı̆̆ zorlukların üstesinden gelme sürecidir. Alanyazında problem çözme farklı şekillerde tanımlanmış olsa da hepsinin ortak noktası bireylerin kendi matematik ve geometrisini oluşturmasına firsat veren, çözümü doğrudan yapılamayan zor durumlara cevap vermesini sağlayan beceriler olarak ifade edilmiştir (Açıkgül ve Aslaner, 2014; Diego-Mas, 2009; Fan, Qi, Liu, Wang ve Lin, 2017; Fisher, Allen ve Kose, 1996; González ve Herbst, 2009; Hoffman ve Schraw, 2009; NCTM, 2000). Günümüzde bilgisayar destekli yazılımlar matematik ve geometri derslerinde problem çözmeye yardımcı materyaller olarak karışımıza çıkmaktadır (Baki, 2002; Çetin, Erdoğan ve Yazlık, 2015; Kawabata ve Itoh, 2009; Wong, Yin, Yang ve Cheng, 2011). Bilgisayar destekli yazılımların öğretim ortamında kullanılması da bilgisayar destekli öğretim kavramını oluşturmaktadır.

Bilgisayar destekli öğretim, bilgisayar programları aracıllğıyla öğrencilere öğretilmek istenen kavramların somutlaştırılarak öğretilmesidir. Bilgisayar destekli geometri öğretimi ise geometrik yapıların ve nesnelerin yazılımlar aracılı̆̆ıyla öğrencilere öğretilmesidir (Bintaş ve Akıllı, 2008; Tapan-Broutin, 2010). Bilgisayar destekli geometri öğretimi, öğrencilerin geometri problemlerine yönelik kendi çözümlerini üretebilmesine imkan tanımakta ve soyut nesneleri kendi kontrolü ile somutlaştırarak öğrenmesini sağlamaktadır. Dolayısıyla bilgisayar destekli yazılımlar öğrenme ortamlarında öğrencileri aktif kılmakta ve öğrencilerin kendi matematiğini/geometrisini oluşturmasına fırsat tanımaktadır. Bu süreçte bilgisayar yazılımları problem durumu ile iç içe verildiğinde kullanılırsa öğrencilerin kavramsal anlamalarında faydalı olmaktadır (Güven ve Karataş, 2003). Bu çalışmada problem çözme becerileri merkeze alınarak geliştirilen bilgisayar destekli geometri etkinlikleri ve öğretmen adaylarının problem çözme stratejileri incelendiğinden, teorik yapı olarak bilgisayar destekli geometri öğretimi ve problem çözme konularına odaklanılmıştır.

\subsection{Problem ve Problem Çözme}

Problem, karmaşık ya da sonucu bilinmeyen bir sorun olarak ifade edilebilir. Problem çözme bireylerin sonuçlarına doğrudan ulaşamadığ veya doğruluğundan hemen emin olamadığ 1 durumlardır (Lester, 1994). NCTM (2000), matematik ve geometri öğretim programlarında 
problem çözme becerisinin merkezde olması gerektiği vurgulanarak matematik öğretmenlerinin öğrencilerin problem çözme becerilerini geliştirecek sınıf ortamlarını oluşturulmalarının önemine dikkat çekmiştir. Problem çözmede matematik ya da geometri problemlerine uygulanacak belirli kalıpta çözüm yöntemleri yoktur. Her problem farklı bir çözüm yolu gerektirebilir. Dolayısıyla karşılaşılan problemlere yönelik çözüm kalıpları oluşturmak yerine, problemin çözümünün dinamik ve döngüsel doğasını anlayabileceğimiz bir çerçeveye ihtiyaç duyulmaktadır. İşte bu aşamada Şekil 1'de verilen Polya (1990) tarafından sunulan problem çözme basamakları devreye girmektedir.

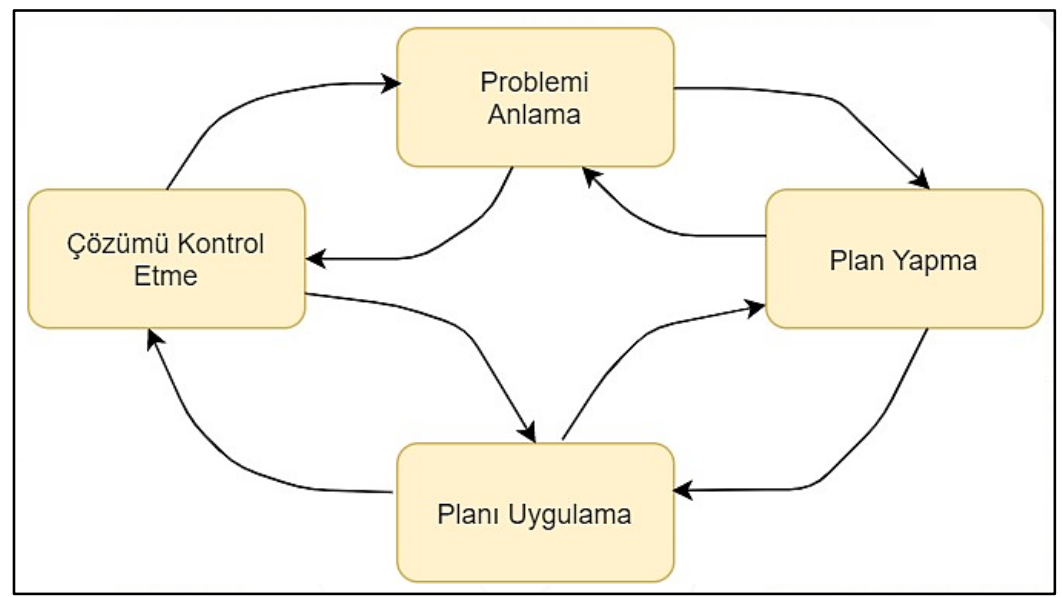

Şekil 1. Problem Çözme Basamakları

Şekil 1'de problem çözmenin dört basamağının bulunduğu görülmektedir. Bunlar, problemi anlama, plan yapma, problemi uygulama ve çözümü kontrol etme şeklindedir.

Problemi anlama basamağında verilenlerin kendi cümleleri ile ifade edilmesi, problemin anlatımına uygun şekil çizme ve problemde verilenler ile istenilenleri yazma şeklinde göstergeleri vardır. Plan yapma basamağ ; problemin çözümüne uygun plan yapma ve bu planı matematiksel cümlelerle ifade etme şeklindedir. Planı uygulama basamağ çözümünde kullanılacak yöntem ve stratejilerin uygulanmasıdır. Son olarak çözümü kontrol etme basamağı adından da anlaşılacağı üzere problemin çözümünde yapılan yöntem ve stratejilerin sağlamasının yapılmasıdır. Bu basamakta yapılan çözüm doğru ise döngü sonlandırılır. Problem ile problem çözme tanımlarının ardından bu konuda önem kazanan kavramlardan bir diğeri de çözme becerisi olmuştur. Problem çözme becerisi; bireylerin karşılaştığ 1 problemlerin üstesinden gelme yeteneği olarak tanımlanır (Surya, Andriana ve Mukhtar, 2017).

Surya, Andriana ve Mukhtar (2017) ile Novita, Zulkardi ve Hartono (2014), NCTM'de (2000) problem çözme becerilerinin göstergelerini

- problemde nelerin verildiği, nelerin istenildiği, istenilene ulaşmak için nasıl bir yol izleneceği gibi öğeleri tanımlayabilme,

- verilen bir matematiksel problemi formüle edebilme veya matematiksel bir model oluşturabilme,

- problemin çözümüne yönelik stratejiler uygulayabilme,

- sonuçları yorumlayabilme,

- matematiksel dili etkili kullanabilme şeklinde ifade etmişlerdir.

Problem çözme becerilerinin etkili kullanılabilmesi için, çözüme yönelik uygun stratejilerin geliştirilmesi de oldukça önemlidir. Problem çözme stratejileri de öğrencilerin, farklı tarzda ve rutin olmayan problemler ile karşılaşması ile mümkün olabilmektedir (Lester, 
1994). Bu çalışmada da öğretmen adaylarının bilgisayar destekli ortamlarda geometri problemi çözme stratejilerine odaklanılmıştır.

\subsection{Bilgisayar Destekli Geometri Öğretimi ve Problem Çözme}

Bilgisayar destekli problem çözme; öğrencilerin problem çözme becerilerinin geliştirilmesinde ve problem çözme etkinliğini zevkli hale getirmede kullanılan bir yöntem olarak tanımlanmaktadır (Baki, 2008). Bilgisayar destekli geometri eğitiminin problem çözme ile iç içe olması geometrik yapıların görselleştirilmesinde, soyut kavramların somut hale getirilmesinde, geometrik şekiller arasında ilişkilendirme yapılıp ve muhakame kurulmasında, yapılan çözümlerin kontrolünün sağlanmasında yardımcı olmaktadır (Bülbül, Güler, Gürsoy ve Güven, 2020).

Alanyazında bilgisayar destekli yazılımların problem çözme ile ilişkilendirildiği bazı çalışmalara rastlanmaktadır (Aparı, 2019; Christou, Mousolides, Pittalis ve Pitta-Pantazi, 2005; Bülbül, Güler, Gürsoy ve Güven, 2020; Çetin ve Mirasyedioğlu, 2019; Güven ve Karataş, 2003; Kuzle, 2013; Roza, 2017; Santos-Trigo ve Espinosa-Perez, 2010). Bunlardan biri Christou vd. (2005) tarafindan yürütülen öğrencilerin problem çözme ve kurma süreçlerinde dinamik yazılımların etkisinin araştırıldığı çalışmadır. Christou vd. (2005) bu çalışmasında öğrencilerin problem çözme ortamlarında dinamik geometri yazılımlarını kullanma şekillerine odaklanmıştır. Araştırmacılar çalışmaların sonucunda dinamik geometri yazılımının sürükleme ve ölçme fonksiyonlarının bilişsel çatışmalar oluşturmak suretiyle problem çözme süreçlerini desteklediği saptanmışır. Kalem-kâğıt ortamının sunamadığı özel durumları göz önünde bulundurma, yazılım aracılığıyla öğrencilerin problem çözme süreçlerini desteklemiştir. Benzer şekilde Kuzle (2013), dinamik geometri yazılımlarından biri olan Geometer's Sketchpad yazılımı aracılığıyla iki öğretmen adayının rutin olmayan geometri problemlerini çözerken ortaya koydukları süreçleri tanımlamayı amaçlamıştır. Kuzle (2013) çalışmasının sonucunda öğretmen adaylarının araştırma, planlama, uygulama ve doğrulama aşamalarında bilgi ve stratejilere erişmek ve bunları değerlendirme, varsayımlarda bulunma ve bu varsayımları test etme, ilerlemeyi görüntüleme ile faaliyetlerin ve stratejilerin etkililiği ve ulaşılan yanıtın doğruluğunu değerlendirmek için kararlar aldığını ifade etmiştir. Açıkgül (2012) ise matematik öğretmeni adayları ile yürüttüğü çalışmasında öğretmen adaylarının geometrik yer problemlerini çözümleri sürecinde dinamik geometri yazılımlarından Cabri Geometry'nin etkisini incelemiştir. Etkinliklerle zenginleştirilen uygulama süreci kalem kâğıt ortamında yürütülen etkinliklerin yanında dinamik geometri yazılımları ile zenginleştirilmiştir. Çalışmadan elde edilen sonuçlar, adayların kalem kâğıt ortamında yaptıkları çözümlerin hatalar içerdiğini, yazılımda ise adayların eksik alan bilgilerinin olduğu bulgularına rastlandığı görülmüştür.

Aslında yukarıdaki göstergeler incelendiğinde hem Polya'nın hem de Schoenfeld'in (1992) problem çözme sürecini içerdiği görülmektedir. Son yıllarda bilim ve teknolojinin gelişimi ile yukarıda yer alan göstergelerden biri olan problemin çözümüne yönelik stratejilerinin uygulayabilme kriteri de boyut değiştirmiştir. Bu kriter daha çok bilgisayar destekli öğretim ile problem çözümüne yönelik stratejiler geliştirebilme aşamasına geçmiştir.

Kaur, Har ve Kapur (2009) problem çözme becerileri odaklı bilgisayar destekli etkinliklerin özelliklerini aşağıdaki şekilde açıklamıştır.

- Öğrencilere rutin olmayan problemler verilmelidir. Rutin olmayan problemlerde öğrenciler sonuca doğrudan ulaşamayacakları için çözüme yönelik uygun stratejileri seçmeye çalışırlar.

- Açık uçlu problemlere yer verilmelidir. Açık uçlu problemlerde öğrencilerin yaptığı çözümler, çözüme yönelik modellemeleri ve matematiksel dili etkili kullanıp kullanmadığı daha kolay anlaşılmaktadır.

Sonuç olarak geometri problemlerini çözme sürecinin verimli olabilmesi ve öğrencilerin farklı çözüm stratejilerine yönlendirilebilmesi için Wong, Yin, Yang ve Cheng'in (2011) ifade 
ettiği gibi kâğıt kalem süreci ile dinamik geometri yazılımlarında geometrik yapıyı oluşturma sürecinin iç içe olması gerekmektedir. Öğrenciler dinamik geometri yazılımlarını sadece görselleştirme ya da sonuca ulaşma amacıyla kullanmamalı yazılımlar aracılığılla problemlerin çözümlerinin sebebini araştırmalıdır. Ancak ilgili alanyazında daha çok öğrencilerin bilgisayar destekli yazılımları kullanmalarının belirlenen bir konu üzerindeki başarısına olan etkisine odaklanılmıştır (Akbaş ve Baki, 2020; Bayturan, 2011; Bintaş ve Bağcivan, 2007; Genç ve Öksüz, 2016; Hangül ve Üzel, 2010; Kertil, 2020; Orçanlı ve Orçanl1, 2016; Özdemir, Aslaner ve Açıkgül, 2020; Yemen, 2009; Zengin ve Akçakın, 2021). Bu durum da bilgisayar destekli yazılımların öğrenmede yardımcı bir etken olması amacından uzaklaştırarak sadece öğrencilerin akademik başarısına yönelmesini sağlamaktadır. Oysa bilgisayar destekli geometri öğretimi, soyut teoremleri ve aksiyomları somutlaştırarak öğrencilerin kavramsal boyutta öğrenmelerini sağlayan bir araçtır. Bu aracın etkili kullanılabilmesi için de öğrencilere verilen problemlerin sadece sonuçlarına değil, problem çözüm süreçlerine odaklanılması gerekmektedir. Bu süreçte öğrencilerin hangi problem çözme stratejilerini ne şekilde kullandıklarını belirlemek, çözümün kontrolü açısından oldukça önem taşımaktadır. Ancak alanyazında geometri problem çözüm stratejilerinden çok, başarıya odaklanılmış olması sürece odaklanmada eksiklikler olduğunu göstermektedir. Dolayısıyla bu çalışma ile söz konusu eksikliğin giderilmesi sağlanarak alanyazına bilgisayar destekli ortamlarda kullanılan problem çözme stratejilerinin katk1 sağlayacak olması araştırmanın gerekçe ve önemini oluşturmaktadır. Dolayısıyla bu çalışmada dinamik geometri yazılımlarından biri olan GeoGebra aracılığıyla farklı çözüm stratejilerini kullanmaya yönelik problemler hazırlanmış ve bir dönem boyunca matematik öğretmeni adaylarına uygulanmıştır. Bu çalışma ile matematik öğretmeni adaylarının bilgisayar destekli ortamda geometri problem çözme stratejilerinin belirlenmesi amaçlanmıştır. Bu amaç doğrultusunda çalışmada "Bilgisayar destekli ortamda geometri problemleri çözülürken hangi stratejiler kullanılmalıdır?" sorusuna cevap aranmaktadır.

\section{YÖNTEM}

Bu çalışmada sınırlı sayıda katılımcıların problem çözme stratejilerini kullanımları incelendiğinden özel durum çalışması yöntemi kullanılmıştır. Özel durum çalışmasında, bir durum üzerine yoğunlaşlarak, o duruma ilişkin çeşitli faktörlerin etkileşimi bütüncül bir yaklaşımla ortaya konulmaktadır (Cohen ve Manion, 1994; Creswell, 2007; Çepni, 2007).

Çalışmanın uygulamaları aşamasında Manisa Celal Bayar Üniversitesi Sosyal ve Beşeri Bilimler Bilimsel Araştırma ve Yayın Eğiti Kurulu'ndan 06.02.2020 tarih ve 2020/03

\section{sayılı toplantısı ile Etik Kurul Kararı bulunmaktadır.}

\subsection{Katılımcilar}

Bu çalışma bir devlet üniversitesinde 2020-2021 Öğretim Yı1ı Güz Dönemi İlköğretim Matematik Öğretmenliği programı ikinci sınıfta öğrenim gören 14 öğrenciyle yürütülmüştür. Çalışmanın amacı bilgisayar destekli geometri etkinlikleri aracılığıyla matematik öğretmeni adaylarının problem çözme becerilerinin belirlenmesi olduğundan, çalışmanın seçmeli ders olan "Bilgisayar Destekli Matematik Öğretimi" dersini alan öğretmen adayları ile yürütülmesi uygun görülmüştür. Ayrıca öğretmen adaylarına bir dönemlik uygulama sonucunda "Problem Çözme Başarı Testi" uygulanmıştır. Uygulamayı yapan 14 öğretmen adayı arasından seçilen 6 öğretmen adayı ile yaptıkları problemlerin çözüm sürecine yönelik klinik mülakatlar yürütülmüştür. Öğretmen adayları seçilirken problem çözme başarı testinde kullandıkları stratejilere göre iyi, orta ve düşük seviyelere göre sınıflandırılmıştır. Her bir seviyeden 2 şer öğrenci seçilmiştir. Bu sebeple gerek örneklem seçiminde gerekse mülakatların yürütülmesinde bahsedilen temel kriterler çerçevesinde hareket edildiğinden amaçlı örnekleme (Palinkas vd., 2015) yapıldığ 1 söylenebilir. 


\subsection{Veri Toplama Araçları}

Çalışmada veri toplama araçları olarak Problem Çözme Başarı Testi, bilgisayar destekli ortamda uygulamaya yönelik problemler, araştırmacı alan notları ve klinik mülakatlar kullanılmıştır. Aşağıda veri toplama araçlarına ait ayrıntılı bilgilendirme verilmiştir.

Problem Çözme Başarı Testi önceden bir proje kapsamında araştırmacılar tarafından geliştirilmiştir (Bülbül, 2021). Teste ait geçerlik çalışması iki aşamalı olarak yürütülmüştür. Bunlardan ilki kapsam ve yapı geçerliğidir. Kapsam geçerliğini sağlamak amaciyla ölçme aracının söz konusu becerileri örtecek şekilde var olup olmadığı, kapsam geçerliği için ise problemlerin ölçülmek istenen beceriyi ölçmedeki rolü göz önünde bulundurulmuştur. Her iki geçerlik türünü sağlamak amacıyla hazırlanan problemler beş matematik eğitimi doktorantı tarafından ayrı ayrı incelenerek içerik ve ölçülmesi hedeflenen boyutlara hizmet etme açısından ayrı ayrı incelenmiştir. İkinci olarak görünüş geçerliğinin sağlanması amacıyla bir dil uzmanından da destek alınarak problemlere son hali verilmiştir. Problem çözme başarı testine ait güvenirlik çalışması ise Rasch analizi kullanılmıştır. İlk aşamada test farklı bir örneklem grubuna uygulanmış ve uygulamalardan elde edilen verilerle yapılan analizler sonucunda kişi güvenirlik katsayısı 0.69, madde güvenirlik katsayısı ise 0,82 olması çıkmıştır. Her iki değer de problem çözme başarı testinin iyi düzeyde güvenilir olduğunu göstermektedir (Bond ve Fox, 2013). [Çalışmada kullanılan ölçeğin geliştirilme adımları hakkında detaylı bilgi için bkz. Bülbül (2021)].

$\mathrm{Bu}$ test öğretmen adaylarının farklı problem çözme becerilerini harekete geçirmeye yönlendirici toplam 10 açık uçlu problemden oluşmaktadır. Tablo 1'de testte yer alan problemlere ait ayrıntılı bilgilere yer verilmiştir.

Tablo 1. Problem Çözme Başarı Testinde Yer Alan Problemlerin İçeriği

\begin{tabular}{cl}
\hline Problem No & Problemlerin İçerikleri \\
\hline 1 & Üçgende açı-kenar uzunluğu ilişkisi \\
2 & Dörtgenler (Yamuk ve özellikleri) \\
3 & Dörtgenler (Kare ve özellikleri) \\
4 & Üçgende kenarortayın özellikleri \\
5 & Dörtgenler (Dikdörtgen ve özellikleri) \\
6 & Dörtgenler (Paralelkenar ve özellikleri) \\
7 & Eşkenar üçgen ve özellikleri \\
8 & Üçgende alan-kenar uzunluğu ilişkisi \\
9 & Dik üçgen ve özellikleri \\
10 & Çember ve özellikleri \\
\hline
\end{tabular}

Problemlerin içerdiği konular üçgenler, dörtgenler ve çember şeklindedir. Birinci problemde bir üçgen ve bu üçgene ait bazı kenar uzunlukları ve açılar verilmiştir. Öğretmen adaylarından beklenen davranış bu özellikleri kullanarak istenilen iki kenar uzunluğu arasında bir ilişki bulmasıdır. Íkinci problemde bir dik yamuğun bazı kenar uzunlukları ve açıları verilmiştir, istenilen uzunluğun bulunması beklenmektedir. Üçüncü problemde kare içerisine bir üçgen yerleştirilmiştir. Verilenlere göre iki üçgenin birbirine eş olduğunun gösterilmesi adaylardan beklenmektedir. Aslında burada öğretmen adaylarının hem üçgenlerde eşlik hem de karenin özelliklerini bilmesi ve bu özellikleri problem çözümünde kullanması gerekir. Dördüncü problemde bir üçgenin kenarortaylarının kesim noktasından $180^{\circ}$ döndürülmesi ile oluşan yeni şeklin alanı sorulmaktadır. Adayların bu problemi çözebilmesi için hem üçgenin kenarortaylarının özelliklerini bilmesi hem de üçgende kenar uzunluğu ve alan ilişkisini uygulayabilmesi gerekir. Beşinci problemde bir dikdörtgen verilmiştir. Öğretmen adaylarından dikdörtgenin bir köşesinden katlama yapılması sonucu oluşan şekil üzerinde uygulamalar yapılarak istenilen kenar uzunluğunun bulunması beklenmektedir. Adaylar bu problemi çözerken hem dikdörtgenin özelliklerini hem de üçgenlerde benzerlik kuralını bilmesi gerekir. Altıncı problem paralelkenar ve özelliklerini içeren bir soru niteliğindedir. Bu problemi 
çözerken adaylar iki paralel doğru arasında kalan açıların özelliklerini ve üçgenlerde benzerlik konularına hâkim olmalıdır. Yedinci problem eșkenar üçgenin özelliklerini kullanarak eș üçgenlere ulaşmaya yöneliktir. Bu problemi yaptıktan sonra adaylardan aynı özelliği kare ve düzgün beşgen için uygulamaları beklenir. Bütün işlemleri yaptıktan sonra ise genel bir kural oluşturmaları beklenmektedir. Sekizinci problem üçgende alan ve kenar uzunluğu ilişkisi kurmaya yöneliktir. Dokuzuncu problemde öğretmen adaylarından "Dik üçgende hipotenüse ait kenarortay uzunluğunun hipotenüsün uzunluğunun yarısına eşittir." önermesinin doğruluğunu ispatlamaları istenir. Son olarak onuncu problemde bir öğretmenin çembere ait uç durumları düşünerek yaptığı bir problemin çözüm aşamaları verilmiştir. Öğretmen adaylarından beklenen davranış bu aşamaları inceleyerek çözümlerin doğru ve yanlışlığı üzerinde yorum yapmalarıdır.

Öğretmen adaylarına bir dönem boyunca uygulama yapıldıktan sonra Tablo 1'de ayrıntılı bir şekilde ifade edilen problem çözme başarı testi uygulanmıştır. Bu testte verdikleri cevaplara göre iyi, orta ve düşük düzey olarak belirlenen 6 öğretmen adayı ile klinik mülakatlar yürütülmüş̧ür. Klinik mülakatlarda adayların yaptığı çözümleri ayrıntılı bir biçimde açıklamaları istenmiştir.

Öğretmen adaylarına bir dönem boyunca rutin olmayan nitelikte problemler verilmiştir. Söz konusu problemler de önceden bir proje kapsamında araştırmacılar tarafından geliştirilmiştir (Bülbül, 2021). Problemlerin geçerlik ve güvenirlikleri araştırmacılar tarafindan sağlandıktan sonra toplam 15 farklı rutin olmayan problem matematik öğretmeni adaylarına uygulanmıştır. Tablo 2'de problemler ile ilgili ayrıntılı bilgilere yer verilmiştir.

Tablo 2. Rutin Olmayan Problemlerin İçerdiği Konular

\begin{tabular}{cl}
\hline Problem No & Problemlerin Konuları \\
\hline 1 & Üçgenlerde benzerlik (K.K.K) \\
2 & U̧çenlerde eşlik (K.A.K) \\
3 & Üçgen eşitsizliği \\
4 & U̧çende kenarortay özellikleri ve üçgende alan \\
5 & Menalous teoremi, Seva teoremi ve uygulamaları \\
6 & Üçgende açılar \\
7 & Üçgende açılar \\
8 & Üçgende açıortay ve özellikleri \\
9 & U̧çgende yükseklik ve özellikleri \\
10 & Dörtgenler (Dikdörtgen ve özellikleri) \\
11 & Dörtgenler (Karede katlama etkinliği) \\
12 & Dörtgenler (Yamuk ve özellikleri) \\
13 & Dörtgenler (Paralelkenar ve özellikleri) \\
14 & Çember ve özellikleri (kiriş-teğet olma durumları) \\
15 & U̧çgenin iç teğet çemberi ve çevrel çember uygulamaları \\
\hline
\end{tabular}

Tablo 2'de görüldüğü gibi matematik öğretmeni adaylarına uygulanan problemler üçgenlerde benzerlik, üçgenlerde eşlik, üçgen eşitsizliği, üçgenlerde kenarortay özellikleri ve alan, Menalous Teoremi ve uygulamaları, Seva Teoremi ve uygulamaları, üçgende açılar, üçgende açıortay ve özellikleri, üçgende yükseklik ve özellikleri, dörtgenler ve özellikleri, çember ve özellikleri, üçgenin iç teğet çemberi ve çevrel çember uygulamaları konularını içermektedir.

Çalışmadaki veri toplama araçlarından biri de araştırmacı alan notlarıdır. Matematik öğretmeni adaylarına verilen Bilgisayar Destekli Matematik Öğretimi dersinin yürütücüsü aynı zamanda araştırmacılardan biridir. Dolayısıyla dersin yürütücüsü ders sürecinde öğretmen adaylarının verilen problemi kendi cümleleri ile nasıl ifade ettikleri, problemlerin çözümüne yönelik nasıl plan yaptıkları, çözüm sürecinde kullandığı stratejiler ve yapılan çözümlerin doğruluğuna nasıl karar verdikleri gibi dikkat çeken bölümleri not almıştır. 


\subsection{Uygulama Süreci}

$\mathrm{Bu}$ çalışmada matematik öğretmeni adaylarına 13 hafta boyunca Tablo 2'de verilen ve araştırmacılar tarafından daha önceden geliştirilen problemler uygulanmıştır. Uygulanan problemlerin haftalara göre içeriğine Tablo 3 'te yer verilmiştir.

Tablo 3. Problemlerin Haftalara Göre İçerdiği Konu Dağılımı

\begin{tabular}{|c|c|c|}
\hline Haftalar & Problem No & Problemlerin İçerdiği Konular \\
\hline 1 & & Uygulama süreci hakkında bilgilendirme \\
\hline 2 & & $\begin{array}{l}\text { GeoGebra yazılımının tanıtımı ve yazılımı kullanarak } \\
\text { örneklerin çözülmesi }\end{array}$ \\
\hline 3 & 1 & Üçgenlerde benzerlik (K.K.K) \\
\hline 4 & 2 & Üçgenlerde eşlik (K.A.K) \\
\hline 4 & 3 & Üçgen eşitsizliği \\
\hline 5 & 4 & Üçgende kenarortay özellikleri ve üçgende alan \\
\hline 5 & 5 & Menalous teoremi, Seva teoremi ve uygulamaları \\
\hline 6 & 6 & Üçgende aç1lar \\
\hline 7 & 7 & Üçgende açılar \\
\hline T & 8 & Üçgende açırtay ve özellikleri \\
\hline 8 & 9 & Üçgende yükseklik ve özellikleri \\
\hline 0 & 10 & Dörtgenler (Dikdörtgen ve özellikleri) \\
\hline 9 & 11 & Dörtgenler (Karede katlama etkinliği) \\
\hline 10 & 12 & Dörtgenler (Yamuk ve özellikleri) \\
\hline 10 & 13 & Dörtgenler (Paralelkenar ve özellikleri) \\
\hline 11 & 14 & Çember ve özellikleri (kiriş-teğet olma durumları) \\
\hline 12 & 15 & Üçgenin iç teğet çemberi ve çevrel çember uygulamaları \\
\hline 13 & & $\begin{array}{l}\text { Problem Çözme Başarı Testinin GeoGebra yazılımı desteği ile } \\
\text { uygulanması }\end{array}$ \\
\hline
\end{tabular}

Tablo 3’ten de görüldüğü gibi ilk hafta öğretmen adayları uygulama sürecin hakkında bilgilendirilmiştir. İkinci hafta öğretmen adaylarına daha önceden görmedikleri bilgisayar destekli yazılımlardan biri olan GeoGebra tanıtılmış ve "verilen bir doğru parçasının orta dikmesini bulma, bir çembere dışındaki bir noktadan teğet çizme, doğrudan komut kullanmadan kare ve eşkenar üçgen çizimi" gibi GeoGebra destekli örnek problemler çözülmüştür. 3. haftadan itibaren araştırmacılar tarafından hazırlanan problemler öğretmen adaylarına uygulanmıştır. 13. Haftada uygulamalar bittikten sonra öğretmen adayları ile önceden belirlenen bir tarihte çevrimiçi sınıf ortamı oluşturularak 90 dakikalık bir süre zarfinda Problem Çözme Başarı Testi uygulanmıştır. Bu süre zarfında uygulamayı yapan araştırmacı online olarak öğretmen adaylarının anlamadığı sorularda yardımcı olmak için sistemde beklemiştir. Ayrıca öğretmen adaylarından bu testi çözerken GeoGebra yazılımını kullanmaları istenmiştir.

COVID-19 pandemi sürecinde olunması sebebiyle bu çalışmada "Bilgisayar Destekli Matematik Eğitimi” dersleri Microsoft Teams programı aracılığıyla çevrimiçi öğrenme ortamında yürütülmüştür. Bu programın ekran paylaşımı ile her adayın çözümünün ders anında görülebilmesi, öğretmen adaylarının istediği zaman söz hakkı alarak rahat bir şekilde konuşabilmesi avantaj oluşturmaktadır. Yine öğretmen adaylarına ders sürecinde kamera açma zorunluluğu olmadığı için kendilerini daha rahat ifade etmiş olmaları, ders bittikten sonra anlaşılmayan yerleri kayıttan tekrar izleyerek not alınabilmesi gibi özellikleri verilerin güvenirliği açısından avantaj oluşturmuştur. Şekil 2'de örnek bir problem ve uygulama sürecine yer verilmiştir. 


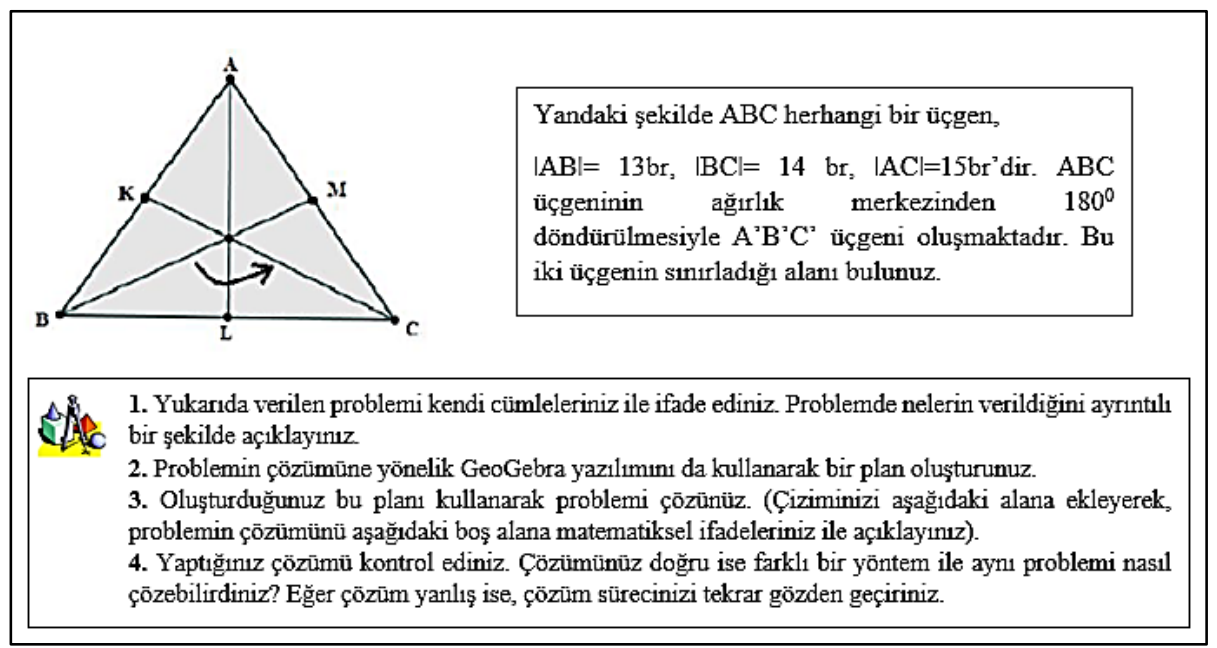

Şekil 2. Beşinci Uygulama Haftasında Uygulanan Dördüncü Problem Örneği

Şekil 2'de beşinci uygulama haftasından örnek bir problem verilmiştir. Bu problem öğrencilere çözdürülürken Polya'nın basamaklarına göre yönergeler içermektedir. Uygulama sürecinin ilk beş haftasında öğretmen adaylarına verilen problemlerin çözümünde Polya'nın basamaklarına göre kendilerine verilen yönergeleri izlemeleri istenmiştir. Bu doğrultuda her bir problem için; (1) Bu problemi kendi cümlelerinizle ifade ediniz, problemde nelerin verildiğini ayrıntılı bir şekilde açıklayınız, (2) Problemin çözümüne yönelik GeoGebra yazılımını kullanarak bir plan oluşturunuz, (3) Oluşturduğunuz bu planı kullanarak problemi çözünüz, (4) Yaptığınız çözümü kontrol ediniz. Çözümünüz doğru ise farkl bir yöntem ile aynı problemi nasıl çözebilirdiniz? Eğer çözüm yanlış ise, çözüm sürecinizi tekrar gözden geçiriniz şeklindeki basamakları ögretmen adaylarından yazmaları istenmiştir. Beşinci haftadan sonra yer alan problemlerde, adayların çözümlerini sınırlandırmamak adına Polya'nın basamaklarına ait yönergelere yer verilmemiştir. Adayların çözümle sürecini, kullandıkları stratejileri problemlerin altına doğrudan yazmaları istenmiştir. Problemlerin hepsi yukarıda da ifade edildiği gibi Microsoft Teams programı kullanılarak Şekil 3'te verildiği gibi yürütülmüştür.

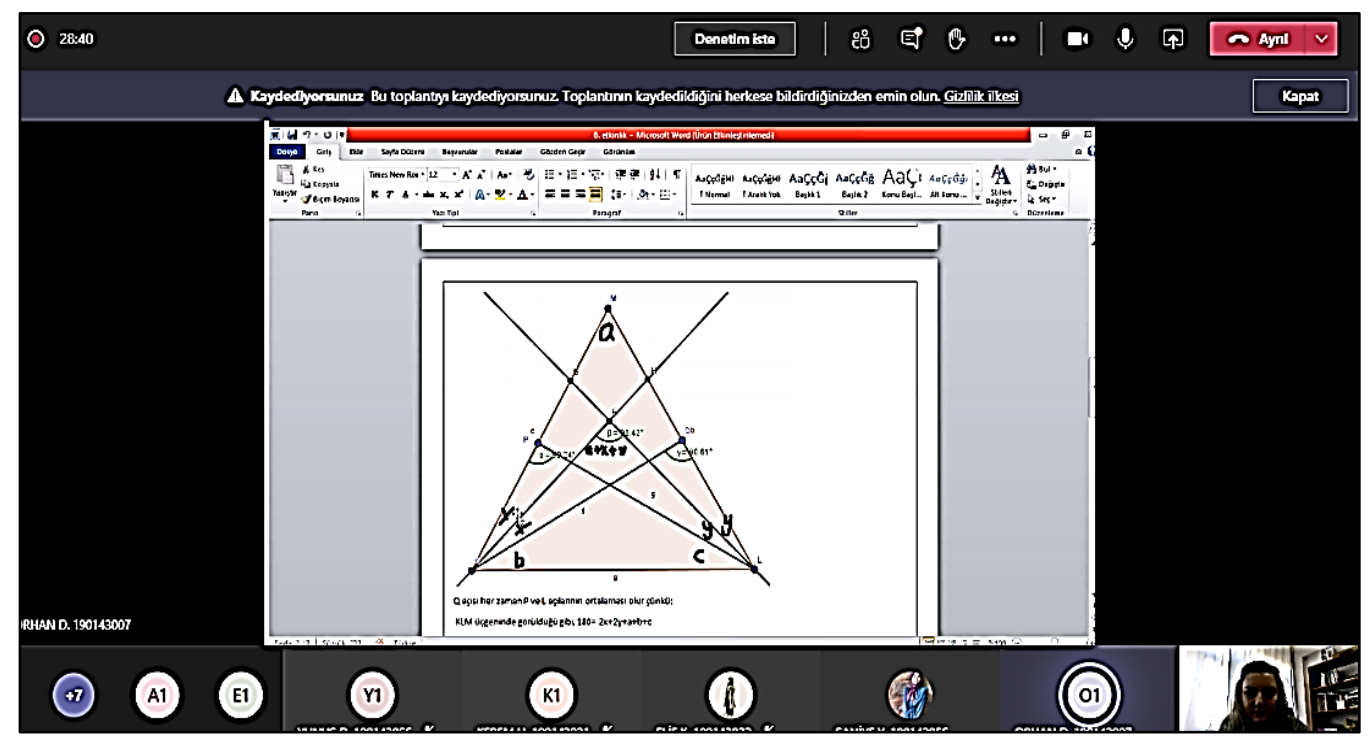

Şekil 3. Bir Öğretmen Adayının Altıncı Haftaya Ait Uygulama Yer Alan Probleme Yönelik Çözümünün Ekran Görüntüsü

Şekil 3'te görüldüğü gibi matematik öğretmeni adayları GeoGebra yazılımını kullanarak yaptığı çözümü ekran paylaşımı yaparak tüm sınıfa açıklamıştır. Burada önemli konulardan biri 
de her hafta etkinlikler uygulamadan iki gün önce dersi yürüten öğretim üyesi tarafından sisteme ödev şeklinde atama yapılmıştır. Öğretmen adaylarına verilen problem durumları alıştırma değil de daha çok araştırma türünden olduğu için, adayların çözümler üzerinde uğraşmasına yönelik ek süreye ihtiyaç duydukları düşünüldüğünden dolayı dersten iki gün önce problemler sisteme atılmıştır. Böylece her aday kendi çözümlerini yapmış ve ders saati geldiğinde farklı çözüm stratejilerini sınıfta paylaşmıştır. Bu şekilde işlenen dersler ile öğretmen adaylarının problem çözme becerilerinin gelişimi de amaçlanmıştır. Ayrıca uygulamalardan önce ve sonra öğretmen adaylarına başarı testi uygulanmıştır. Başarı testinin sonuçlarına göre seçilen 6 öğretmen adayı ile yaptığı testteki cevaplara yönelik klinik mülakatlar yürütülmüştür.

\subsection{Verilerin Analizi}

Çalışmada matematik öğretmeni adaylarının haftalık olarak problemlere "Problem Çözme Başarı Testi" ne verdiği cevaplararaştırmacılar tarafından içerik analizine tabi tutulmuştur. İçerik analizi sonucunda başarı testinde ve etkinliklerde yer alan öğretmen adaylarının kullandığı problem çözme stratejileri araştırmacılar tarafından ayrı ayrı kodlanmıştır. Daha sonra iç geçerlik ve güvenirliği kodlayıcılar arası güvenirlik yüzdesi hesaplanarak sağlanmıştır. $\mathrm{Bu}$ doğrultuda araştırmacıların analizleri problem çözme stratejilerine dayalı kodlara bakılmıştır. Araştırmacıların gerçekleştirmiş olduğu analizlere ilişkin güvenirlik Miles ve Huberman (1994) tarafından önerilen $\frac{\text { Uzlaşma Sayısı }}{\text { (Uzlaşma Sayısı }+ \text { Uzlaşmama Sayısl) }}$ formülü yardımıyla hesaplanmıştır. Puanlama sistemi aracılığıyla gerçekleştirilen analizlerin, kodlayıcılar arası güvenirlik yüzdesi \%94 olarak hesaplanmıştır.

Yukarıda bahsedilen kodlama sürecine örnek oluşturması açısından Ö3 ve Ö5 kodlu öğretmen adaylarının Şekil 2'de verilen probleme yönelik cevaplarını sırasıyla inceleyelim.

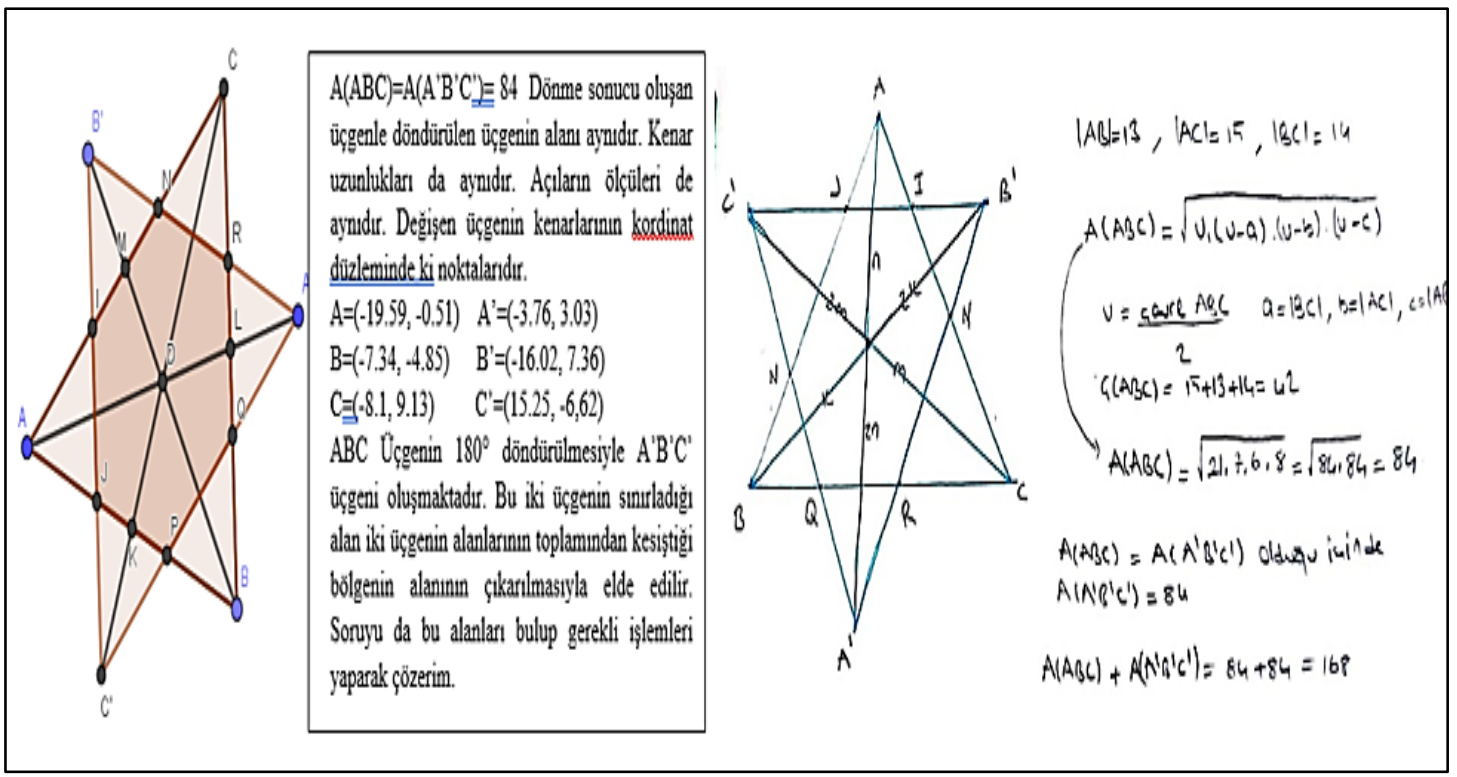

Şekil 4. Ö3 Kodlu Öğretmen Adayının Dördüncü Probleme Yönelik Cevabı

Şekil 4'te Ö3 kodlu öğretmen adayının dördüncü probleme yönelik cevabı verilmiştir. Bu cevap incelendiğinde öncelikle adayın sol taraftaki gibi verilen problemi GeoGebra üzerinde çizdiği, döndürme sonucu oluşan yeni şekle yazılımla baktığı görülmüştür. Bu aşamada Ö3 kodlu öğretmen adayın cevabı ilk önce yazılım kullanarak görselleştirdiği için görselleştirme, stratejisi olarak kodlanmıştır. Daha sonra aynı aday kâğıt kalem yardımıyla yazılım vasıtasıyla döndürdüğü şeklin, değişen ve değişmeyen özelliklerini kullanarak sonuca ulaşmıştır. $\mathrm{Bu}$ aşamada adayın kullandığı ikinci strateji ise döndürme olarak kodlanmıştır. Şekil 5'te Ö5 kodlu öğretmen adayının aynı probleme yönelik farklı bir çözüm stratejisine ait örnek verilmiştir. 


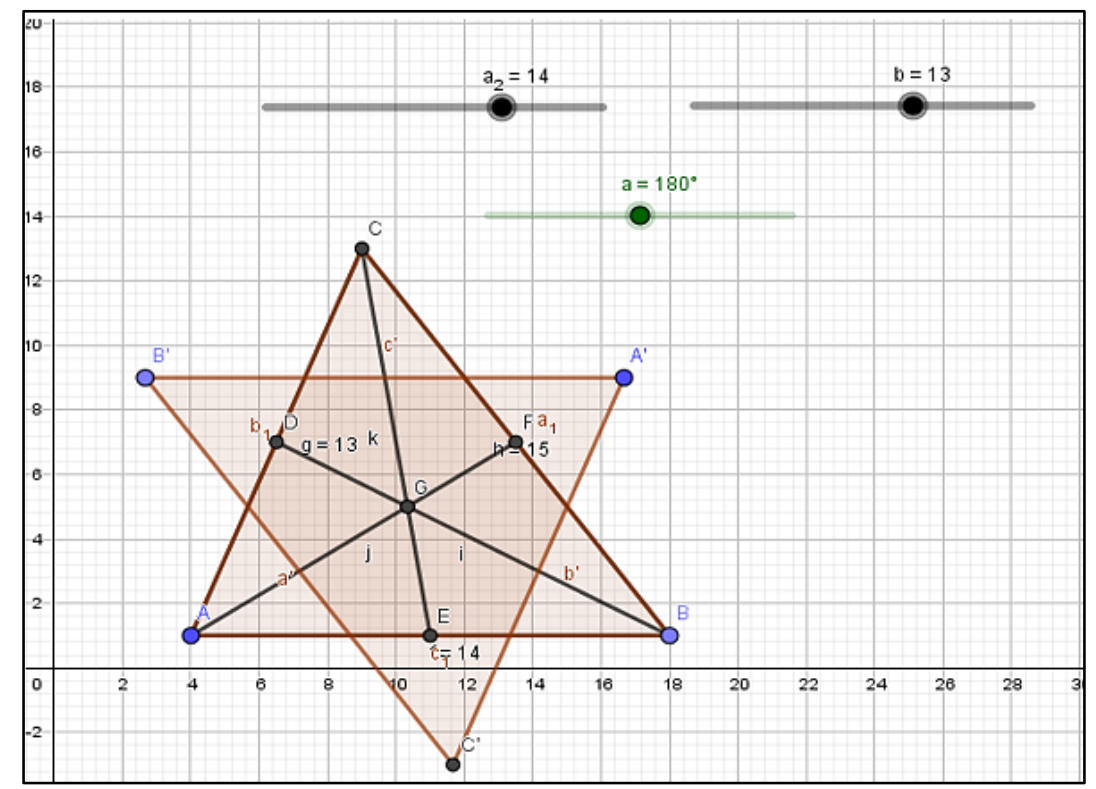

Şekil 5. Ö5 Kodlu Öğretmen Adayının Dördüncü Probleme Yönelik Cevabı

Şekil 5 incelendiğindeÖ5 kodlu öğretmen adayının şekil üzerinde döndürme yaptıktan sonra şeklin belirli kenarlarına ve açılarına sürgü atadığı görülmektedir. Böylece belirlenen kenarlar ve açılar değiştirildikçe, önceki özelliklerin değişip değişmediği kontrol ettiği görüldüğünden Ö5 kodlu öğretmen adayı bu çözüm ile sürükleme stratejisini kullanmıştır. Ayrıca çözümü doğrudan GeoGebra ekranına aktarıp yaptığından görselleştirme becerisini de kullanmıştır.

Yukarıda görüldüğü gibi aynı probleme farklı öğretmen adayları farklı problem çözme strateisi kullanabilir. Öğretmen adaylarının her hafta problemlere yönelik cevapları araştırmacılar tarafından ayrı ayrı incelenmiş ve kodlar oluşturulmuştur. Daha sonra araştırmacılar birleşip ortak kodlar oluşturmuş ve son aşamada öğretmen adaylarının kullandığ problem çözme stratejileri belirlenmiştir.

\section{BULGULAR}

Öğretmen adaylarının dönem boyunca problemlere verdiği cevaplar ile "Problem Çözme Başarı Testi"ne verdiği cevapların analizi sonucunda, bilgisayar destekli ortamda kullandıkları geometri problem çözme stratejileri belirlenmiştir. Şekil 6'da bu stratejilere yer verilmiştir.

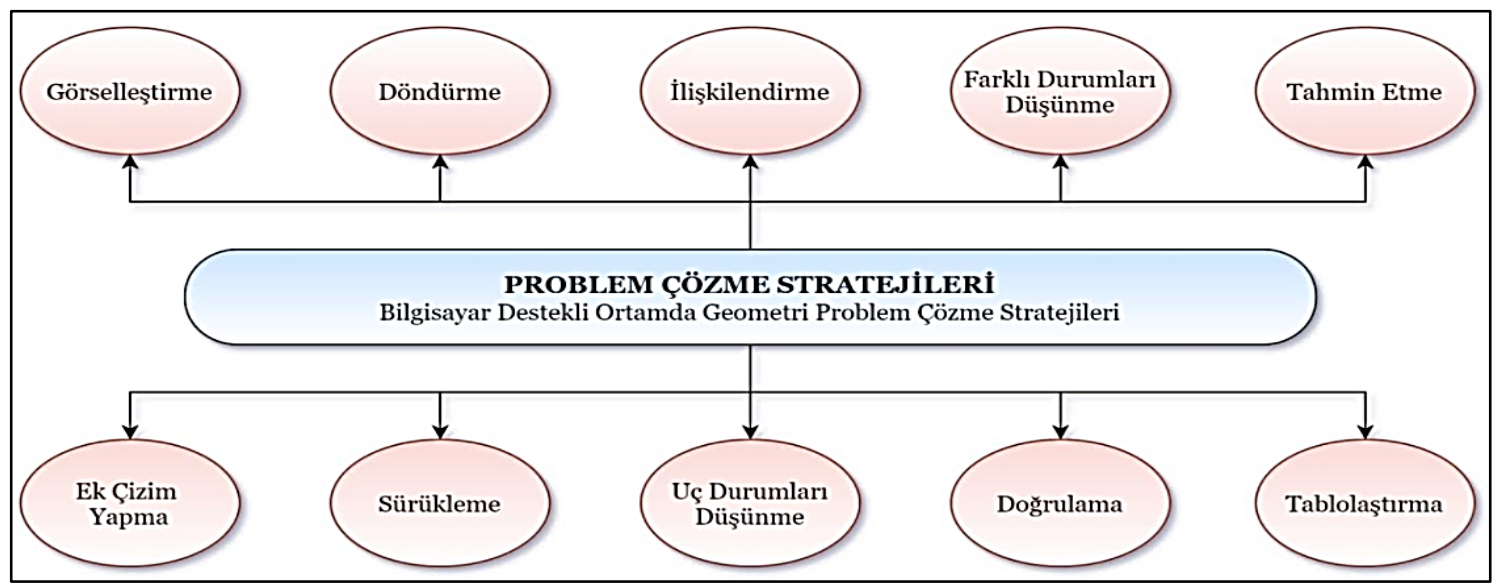

Şekil 6. Bilgisayar Destekli Ortamda Geometri Problem Çözme Stratejileri 
Şekil 6'da GeoGebra desteğiyle hazırlanmış geometri problemlerini çözmeye yönelik stratejiler; görselleştirme, döndürme, ilişkilendirme, tahmin etme, farklı durumları düşünme, ek çizim yapma, sürükleme, uç durumları düşünme, doğrulama, tablolaştırma şeklindedir. Aşağıdaki bölümlerde her bir stratejinin öğretmen adaylarının etkinliklere ve başarı testine verdiği cevaplar ayrıntılı bir şekilde incelenerek açıklanmıştır.

\subsection{Görselleştirme Stratejisi}

Öğretmen adaylarının verdiği cevaplara bakıldığında GeoGebra yazılımı hemen hemen bütün etkinliklerde yer alan problemlerin çözümünde görselleştirme aracı olarak kullandıkları görülmektedir. Ancak bazı durumda yazılım verilen bir problemin çözümüne yönelik sadece görselleştirme amaçlı kullanırken bazı durumlarda ise farklı problem çözme stratejileri ile birlikte kullandığ1 görülmüştür. Şekil 7'de Ö14 kodlu öğretmen adayının ikinci etkinlikteki probleme yönelik cevabı hem ilişkilendirme hem de görselleştirme stratejisinin kullanımına yönelik bir örnektir.

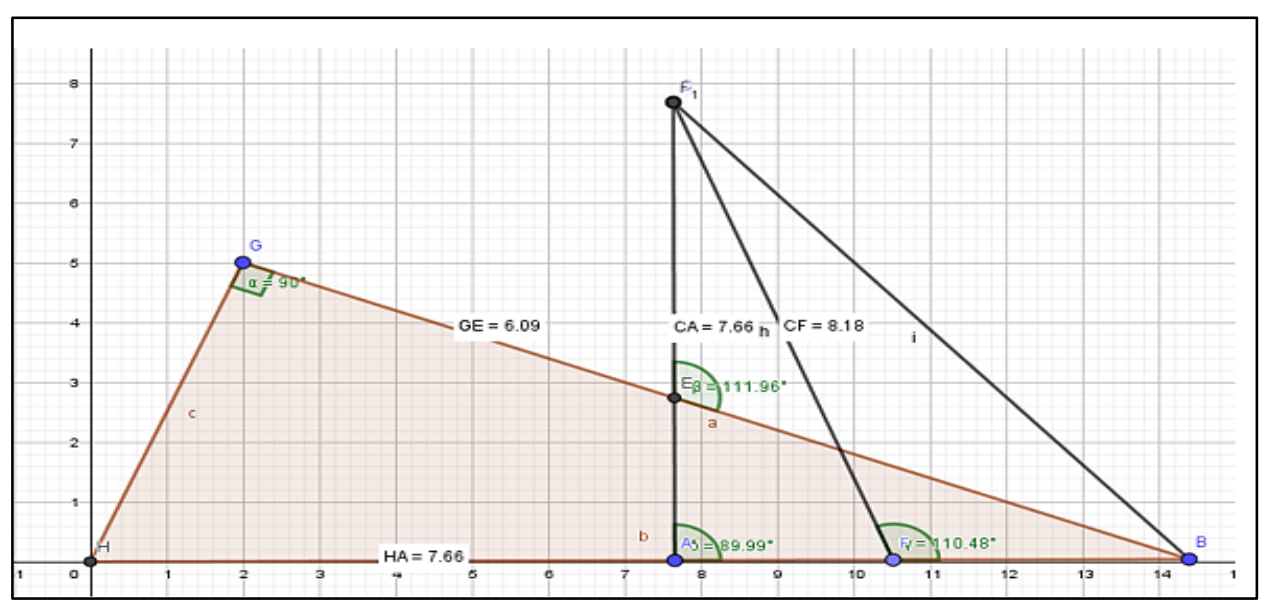

Şekil 7. Ö14 Kodlu Öğretmen Adayının İkinci Probleme Verdiği Cevap

Ö14 kodlu öğretmen adayının Şekil 7'de verilen cevabı incelendiğinde problemi ilk önde GeoGebra'dan çizdiği görülmektedir. Ö14 kodlu öğretmen adayı verilen şekli görselleştirirken aynı zamanda kenar uzunlukları ve açıların ölçülerine bakarak ilişkilendirmelerden de yararlanmıştır. Bazı öğretmen adayları şekli çizerek doğrudan sonuca ulaşıp, verilen problemi bırakmıştır. Bazı öğretmen adayları da Şekil 8'de verildiği gibi şekli görselleştirdikten sonra matematiksel ifadeler ile destekleyerek çözüme ulaşmıştır.

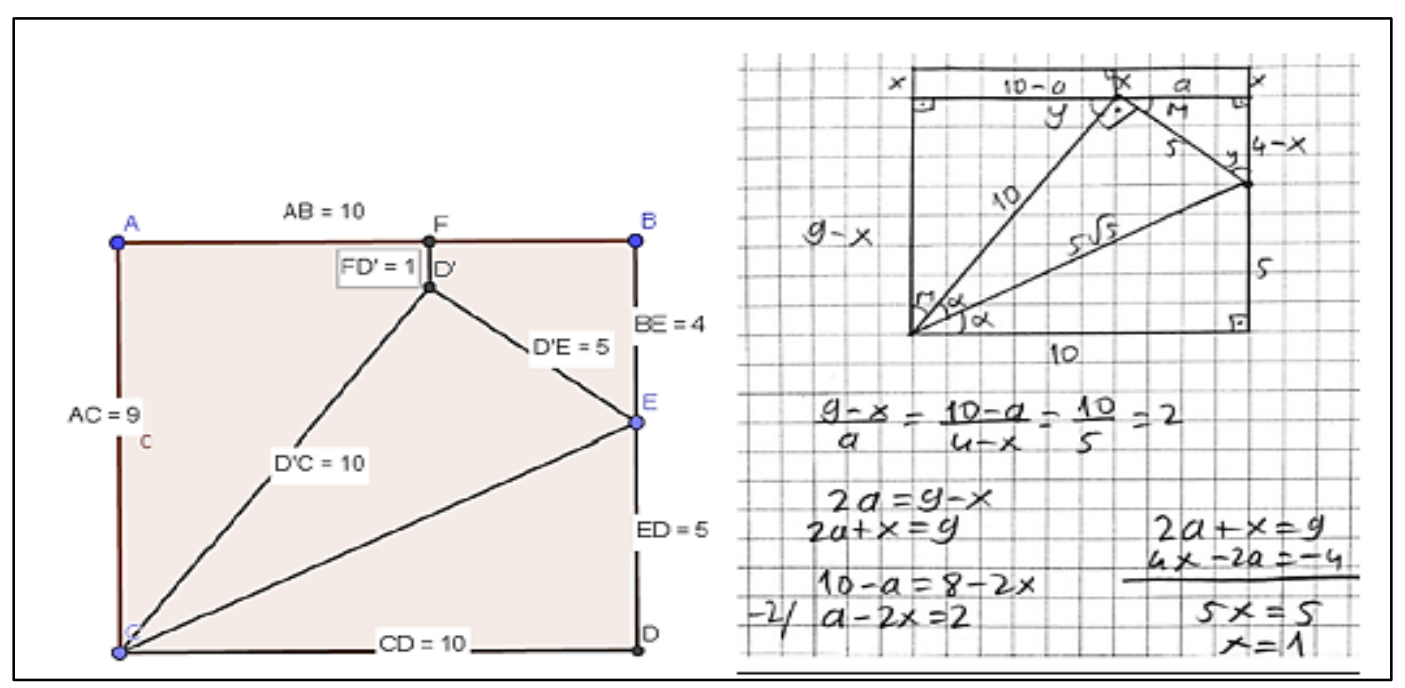

Şekil 8. Ö11 Kodlu Öğretmen Adayının 11. Probleme Verdiği Cevap 
Şekil 8 incelendiğinde Ö11 kodlu öğretmen adayının önce verilen şekli GeoGebra'da çizdiği (sol tarafta) daha sonra da bu çizimi kullanarak kendi çözümünü oluşturduğu (sağ tarafta) görülmektedir. Aday şekil üzerinde verilen uzunlukları ve açıları kendi çiziminde de belirterek doğru sonuca ulaşmıştır.

\subsection{Döndürme Stratejisi}

Öğretmen adaylarının cevaplarına bakıldığında, döndürme stratejisini problemlerin çözümünde kullanırken yazılımdan faydalandıkları görülmüştür. Şekil 9'da Ö3 kodlu öğretmen adayının dördüncü probleme yönelik cevabı verilmiştir.

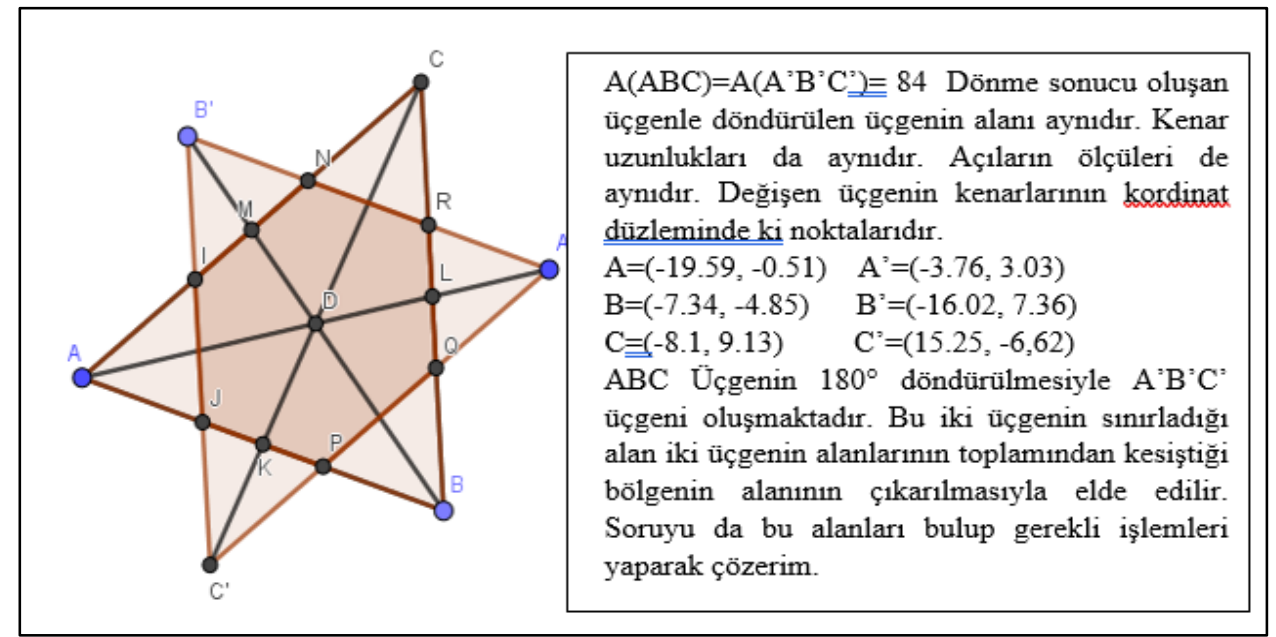

Şekil 9. Ö3 Kodlu Öğretmen Adayının Dördüncü Probleme Verdiği Cevap (a)

Ö3 kodlu öğretmen adayının cevabı incelendiğinde ABC üçgenini kenarortaylarının merkezi etrafinda $180^{\circ}$ döndürülmesi sonucunda elde edilen şekli GeoGebra yazılımını kullanarak çizdiği görülmektedir. Ayrıca öğretmen adayı döndürme sonucunda oluşacak yeni noktaların konumunu tanımlamış ve geometrik yapılar üzerinde değişen/değişmeyen özellikleri belirlemiştir. Yazılımın sürükleme özelliğini kullandıktan sonra oluşan şekil yardımıyla Ö3 kodlu öğretmen adayı Şekil 10'da yer alan kendi çözümünü oluşturmuştur.

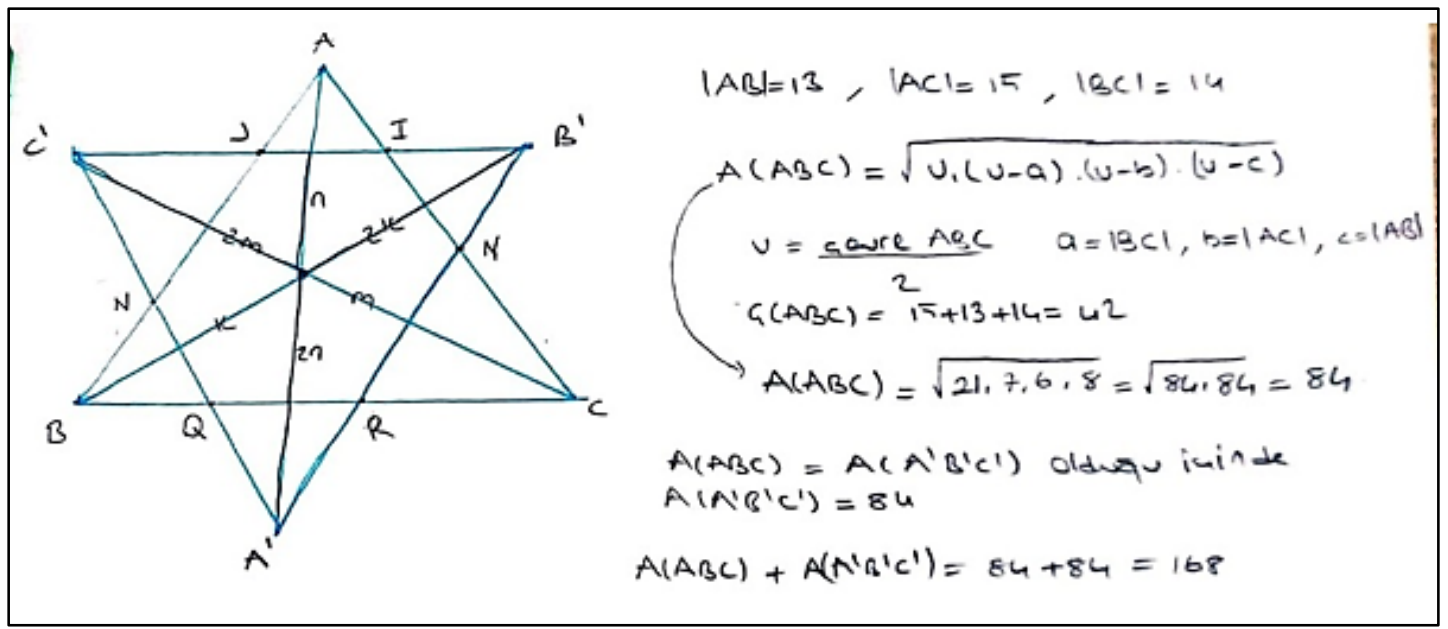

Şekil 10. Ö3 Kodlu Öğretmen Adayının Dördüncü Etkinliğe Verdiği Cevap (b)

Öğretmen adayının Şekil 10'daki cevabı incelendiğinde, yazılımın döndürme özelliğini yeni geometrik yapının oluşmasında ve geometrik şekilde değişmeyen özelliklere bakma aşamasında kullandığı görülmektedir. 
Şekil 11'de verildiği gibi bazı öğretmen adayları da problemlerin çözümünde döndürme becerisini adım adım yazılım yardımıyla kullanmıştır.

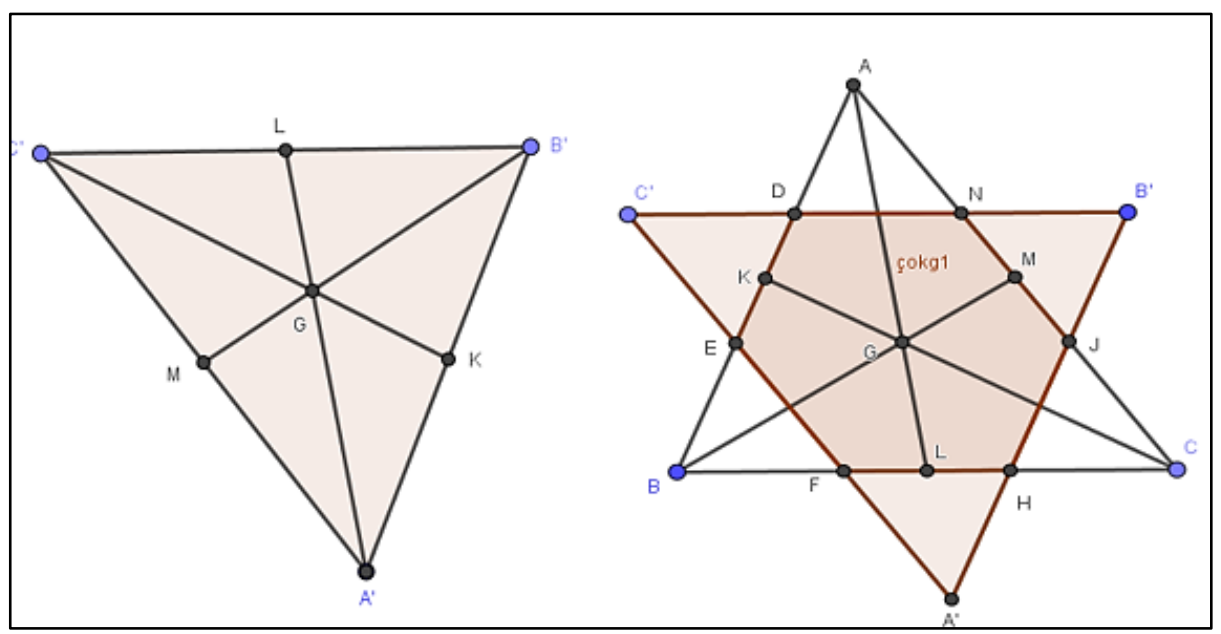

Şekil 11. Ö13 Kodlu Öğretmen Adayının Dördüncü Probleme Verdiği Cevap

Şekil 11 incelendiğinde Ö13 kodlu öğretmen adayının birinci adımda yazılım yardımıyla döndürme yaptığı ikinci adımda ise geometrik şeklin başlangıçtaki hali ile döndürüldükten sonraki halini birleştirdiği görülmektedir. Bu sürecini Ö13 kodlu öğretmen adayı şu şekilde açıklamıştır:

"Öncelikle ă̆ırlık merkezi demek kenarortayların kesişim merkezi demektir. Ve bir şeklin bir nokta etrafinda $180^{\circ}$ dönmesi ise yartm dönme, merkezi dönme ya da noktaya göre simetri olarak dönme demektir. Buna bağll olarak '(1) $A, B$ ve $C$ noktaları değişmiştir strasiyla $A^{l}, B^{l}$ ve $C^{l}$ olmuştur, kenarortay noktaları da değişmiştir, (2) Ağırlık merkezi G ise aynı noktada kalmıştır.' nicelikleri değişir."

Sonuç olarak öğretmen adayları geometri problemlerini çözerken döndürme stratejisini yazılım yardımıyla kullanmıştır. Bu kullanım sonucunda da kendi çözümlerini matematiksel olarak ifade etmişlerdir.

\section{3. İlişkilendirme Stratejisi}

İlişkilendirme stratejisi pek çok problemlerin çözümlerinde farklı şekillerde kullanılabilmektedir. Etkinliklerde öğretmen adayları ilişkilendirme stratejisini verilen geometrik şekilleri arasında veya şekillerin kenar uzunlukları-alanları-çevreleri arasında kullanırken, başarı testinde öğretmen adayları ilişkilendirme stratejisini diğer stratejiler ile iç içe kullanmışlardır. Şekil 12'de verilen ve Ö3 kodlu öğretmen adayının başarı testinde yer alan 3. probleme yönelik cevabı bu duruma örnek gösterilebilir.

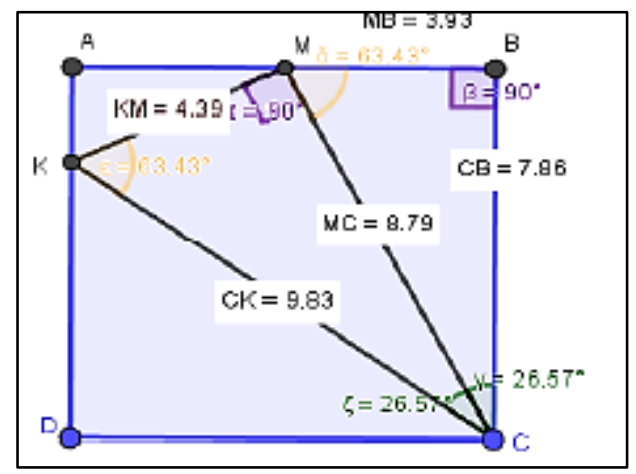

(a)

Şekil 12. Ö3 Kodlu Öğretmen Adayının Başarı Testinin Üçüncü Probleme Verdiği Cevap 
Şekil 12 incelendiğinde Ö3 kodlu adayın problemi ilk önce görselleştirdiği ve istenilen uzunlukları yerleştirerek sonuca yazılım yardımıyla baktığı görülmektedir. Ö3 kodlu aday mülakatta problemi çözme yöntemini şu şekilde ifade etmiştir:

"Hocam problemi çözerken ilk önce şekli programda çizdim. Şekli programda çizdikten sonra üçgenler arasındaki uzunlukları ölçtüm. Uzunlukları not ettim. Açı değerlerini ölçüp açı değerlerini not ettim. Açıların eşit olduklarını uzunlukları arasında da belli bir oran olduğunu gördükten sonra matematiksel olarak da değerler vererek kâğıtta çözdüm."

Öğretmen adayının yukarıdaki açıklaması ve Şekil 12 incelendiğinde, üçgenlerin kenar uzunlukları ile açılarının arasında bir ilişkilendirme yaptığı görülmektedir. Dolayısıyla bu çözüm sürecinde Ö3 kodlu öğretmen adayı ilişkilendirme stratejisini kullanmaya hazırlanmıştır. Ö3 kodlu öğretmen adayının çözümünün devamına Şekil 13'de yer verilmiştir.

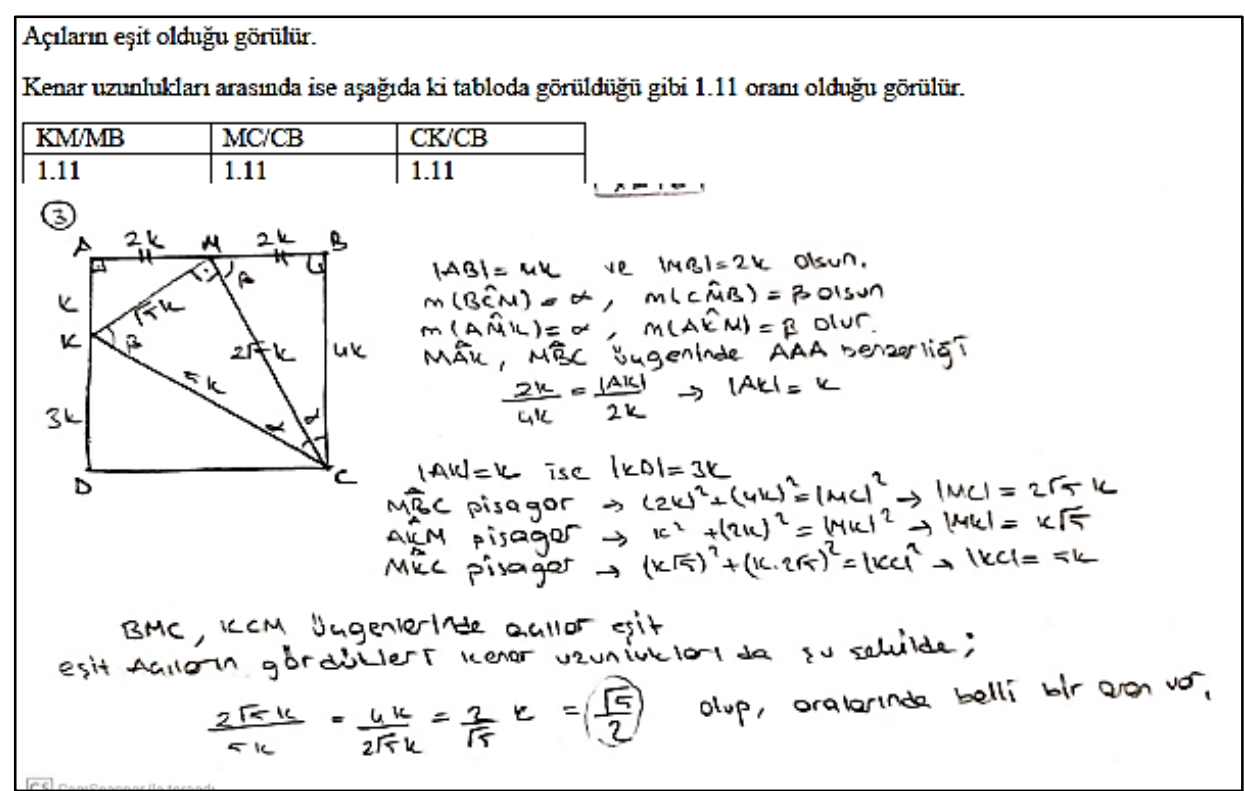
(b)

Şekil 13. Ö3 Kodlu Öğretmen Adayının Başarı Testinin Üçüncü Probleme Verdiği Cevap

Şekil 13 incelendiğinde Ö3 kodlu öğretmen adayının klinik mülakatlarda da ifade ettiği gibi verilenleri GeoGebra'da yerleştirdikten sonra uzunluklar arasında bir oran bulduğu görülmektedir. Bu oranı tablo yaparak arayan Ö3 kodlu aday, sonrasında matematiksel ifadeler ile yaptı̆̆ çözümü desteklemiştir. Dolayısıyla adayın yaptığı bütün bu çözüm süreci sonucunda; görselleştirme, ilişkilendirme, tablolaştırma, tahmin etme ve ek çizim yapma stratejilerini kullandığı söylenebilir. Bazı öğretmen adayları da bir şeklin içerisindeki yapılar arası ilişkilendirme değil birden fazla şeklin birbiri ile ilişkilendirmiştir. Bunlardan biri Şekil 14'te yer alan Ö8 kodlu öğretmen adayıdır.

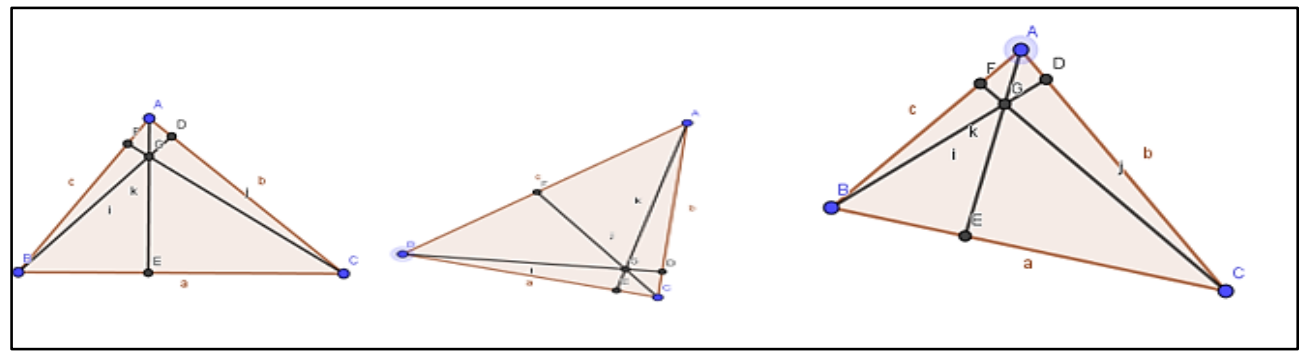

Şekil 14. Ö8 Kodlu Öğretmen Adayının Sekizinci Probleme Verdiği Cevap 
Üçgenlerin yüksekliklerinin noktadaş olduğunu araştıran Ö8 kodlu öğretmen adayı farklı özelliklerdeki üçgenleri çizerek bu önermenin doğruluğunu kontrol etmiştir. Şekil 14'te görüldügü gibi bu işlemi yaparken de GeoGebra'yı ilişkilendirme yapmak amacıyla kullanmıştır. Benzer şekilde Ö11 kodlu öğretmen adayı da farklı bir problemin çözümünde yazılımla birlikte ilişkilendirme stratejisini kullanmıştır (bkz. Şekil 15).

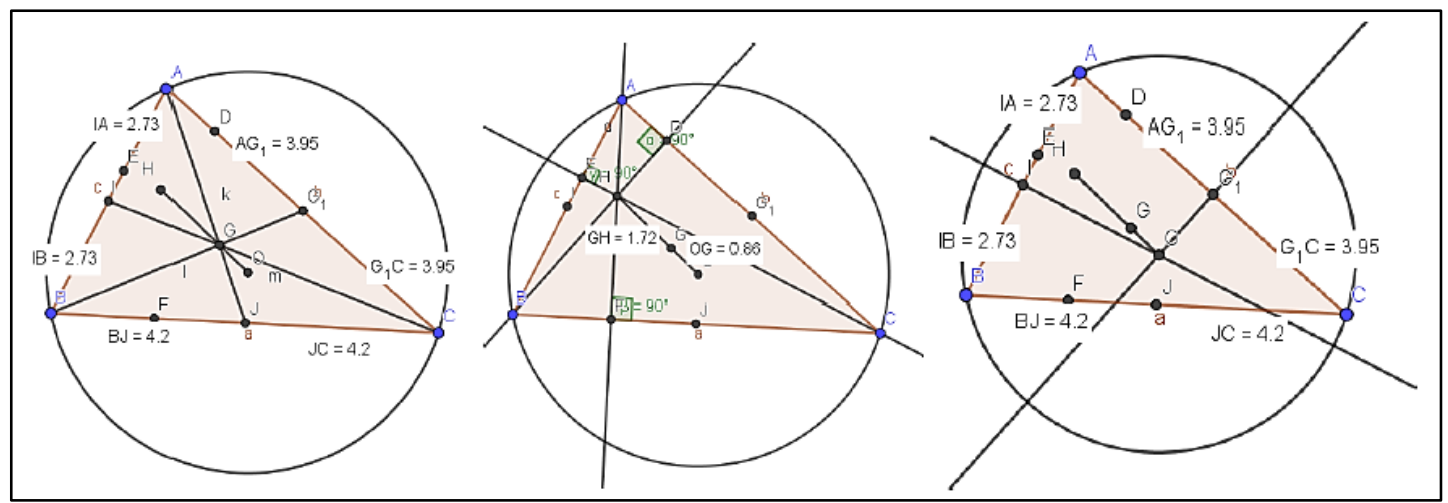

Şekil 15. Ö11 Kodlu Öğretmen Adayının Sekizinci Probleme Verdiği Cevap

Şekil 15'te Ö11 kodlu öğretmen adayının Euler doğru teoreminin doğruluğunu ilişkilendirme stratejisini kullanarak gösterdiği görülmektedir. Bu işlemi gerçekleştirirken yazılım üzerinde üçgenlerin diklik merkezi, çevrel çemberinin merkezi ile ağırlık merkezinin doğrusallığına bakılmıştır. Ö11 kodlu öğretmen adayı bu şekilleri çizdikten sonra, üçgenin yapısını değiştirerek her şartta bu durumun sağlandığını göstermiştir. Dolayısıyla Ö11 kodlu öğretmen adayının diğer stratejilerin yanında bu çizim ile ilişkilendirme stratejisini de kullandiğı görülmektedir.

\subsection{Farklı Durumları Düşünme Stratejisi}

Öğretmen adaylarının cevapları incelendiğinde, problemlerin çözümlerinde farklı durumları düşünme stratejisini kullandıkları gözlemlenmiştir. Şekil 16'da Ö3 kodlu öğretmen adayının 14. probleme verdiği cevapta, farklı durumları düşünme stratejisini kullandığ 1 görülmektedir.

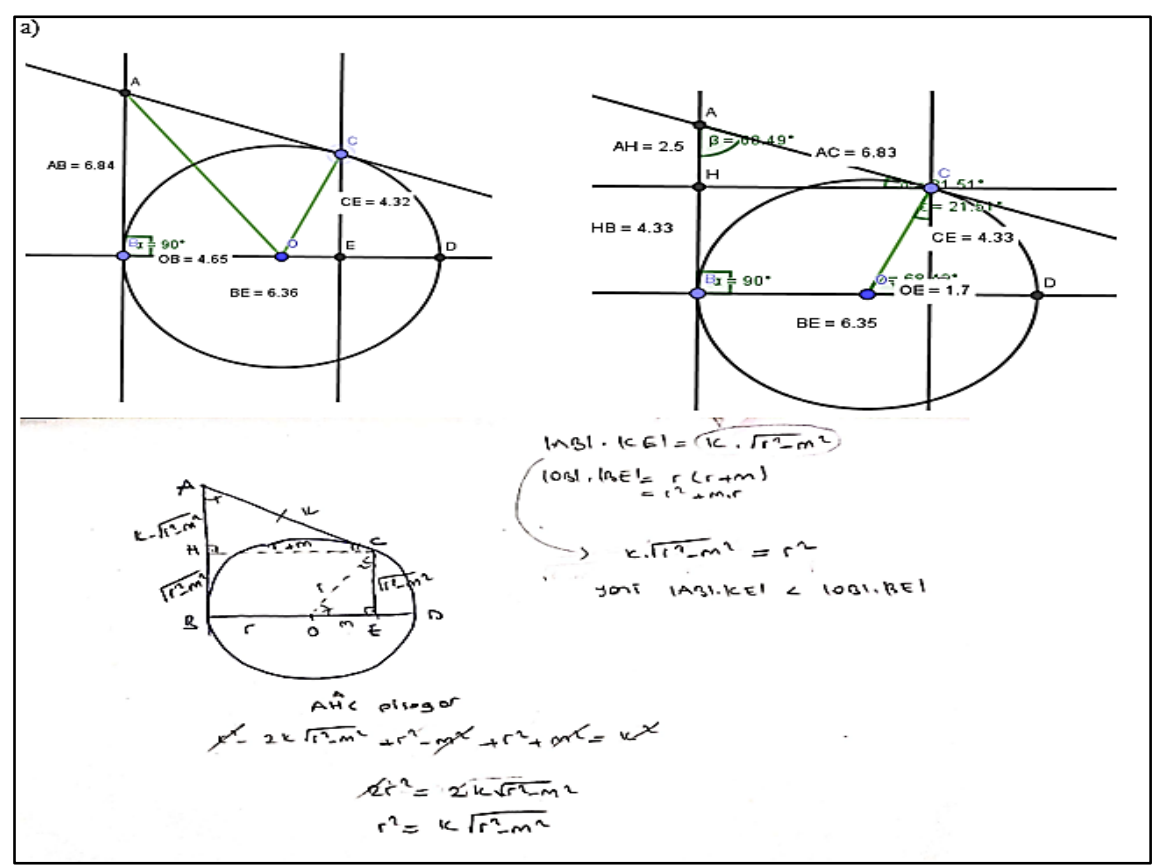

Şekil 16. Ö3 Kodlu Öğretmen Adayının 14. Probleme Verdiği Cevap 
Ö3 kodlu öğretmen adayının Şekil 14'teki cevabı incelendiğinde BE ile BO uzunluklarının çarpımı ile AB ile CE uzunluklarının çarpımına bakarken, çemberlerinin yarıçap uzunluklarını değiştirdiği gözlenmiştir. Farklı durumdaki iki çemberde aynı özelliklerin sağlanıp sağlanmadığı araştırılmıştır. Ö3 kodlu öğretmen adayı yazılımla birlikte farklı durumları düşünme stratejisini kullanırken cevabını matematiksel gerekçeler ile ifade etmiştir.

\subsection{Tahmin Etme Stratejisi}

$\mathrm{Bu}$ çalışmada tahmin etme stratejisi, öğretmen adayları tarafından en çok kullanılan problem çözme stratejilerinden biridir. Bu stratejiyi öğretmen adayları verilen bir geometri problemini çözemediği durumlarda yazılım aracıllğıyla geometrik şekli çizerek, sonuca ulaşma şeklinde kullanmaktadır. Doğru sonuca ulaştıktan sonra adaylar kendi çözümlerine şekil verebilmektedir. Süreçten de anlaşıldığı üzere tahmin etme stratejisi görselleştirme stratejisiyle birlikte kullanılmaktadır.Ö4 kodlu öğretmen adayının Şekil 17'de verilen çözümü bu duruma örnek teşkil etmektedir.

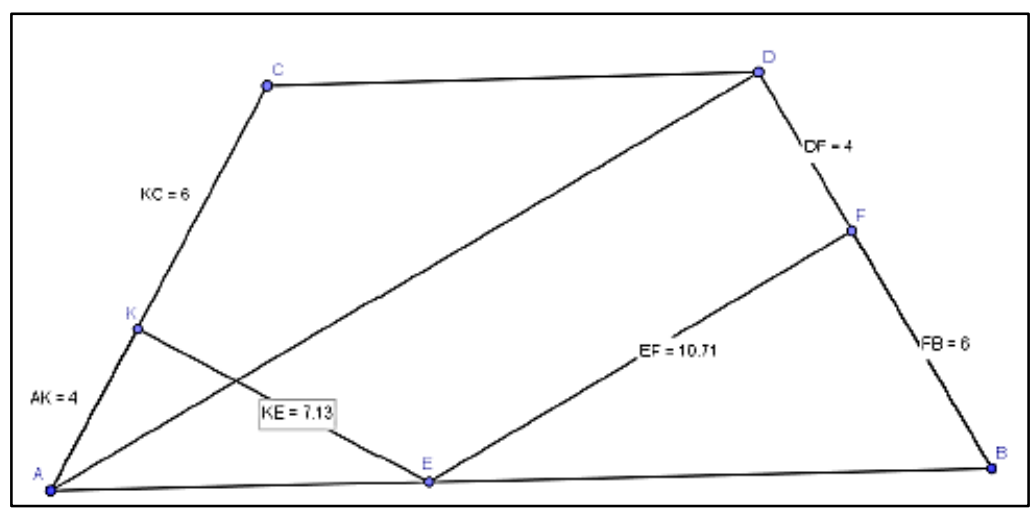

Şekil 17. Ö4 Kodlu Öğretmen Adayının 12. Probleme Verdiği Cevap (a)

Şekil 17 incelendiğinde Ö4 kodlu öğretmen adayının öncelikle problemin şeklini çizdiği daha sonra da istenilen $|\mathrm{AK}|=\mathrm{x}$ uzunluğunu 4 br olarak bulmuştur. Dolayisıyla yazılım yardımıyla tahmin etme stratejisini kullandıktan sonra kendi çözümünü Şekil 18'de verildiği gibi mantıksal gerekçelendirmeler ile açıkladığı görülmektedir.

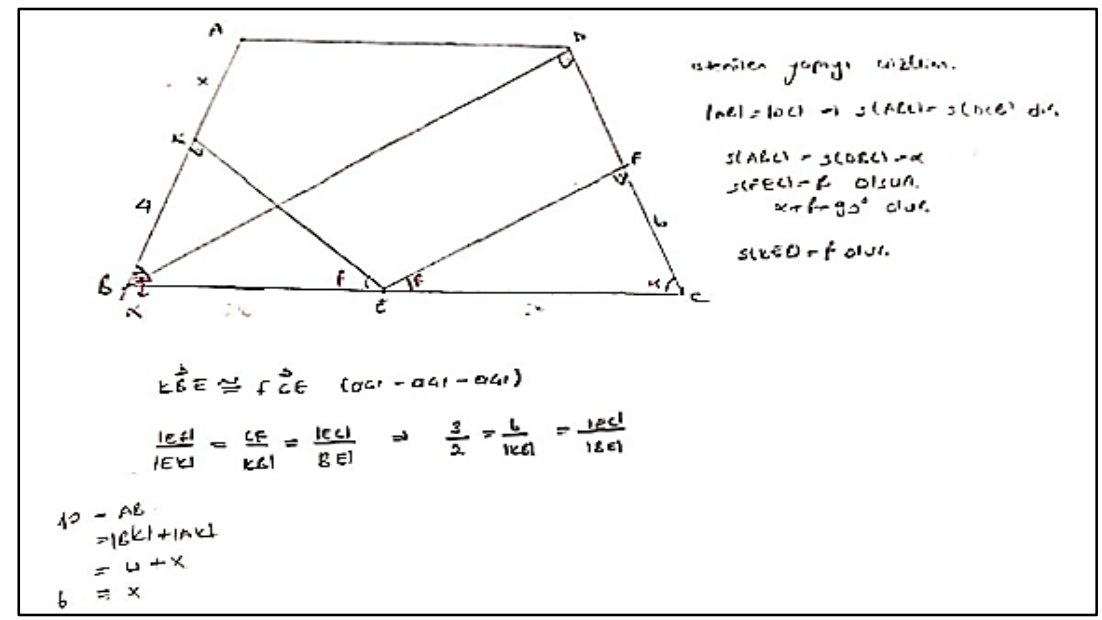

Şekil 18. Ö4 Kodlu Öğretmen Adayının 12. Probleme Verdiği Cevap (b)

Ö4 kodlu öğretmen aday1 12. problemi çözerken önce yazılımı kullanarak problemin sonucuna bakmış daha sonra da kendi matematiksel açıklamalarıyla sonucun doğruluğunu açıklamıştır. Dolayısıyla aday bu çözümleri ile görselleştirme, tahmin etme ve ilişkilendirme stratejilerini kullanmıştır. Bazı öğretmen adayları da geometrik şekiller üzerinde yapılan 
değişikliklerin şekle nasıl yansıdı̆̆ını bulmaya çalışırken tahmin etme stratejisini kullanmıştır. Şekil 19'da bu duruma örnek bir çözüm verilmiştir.

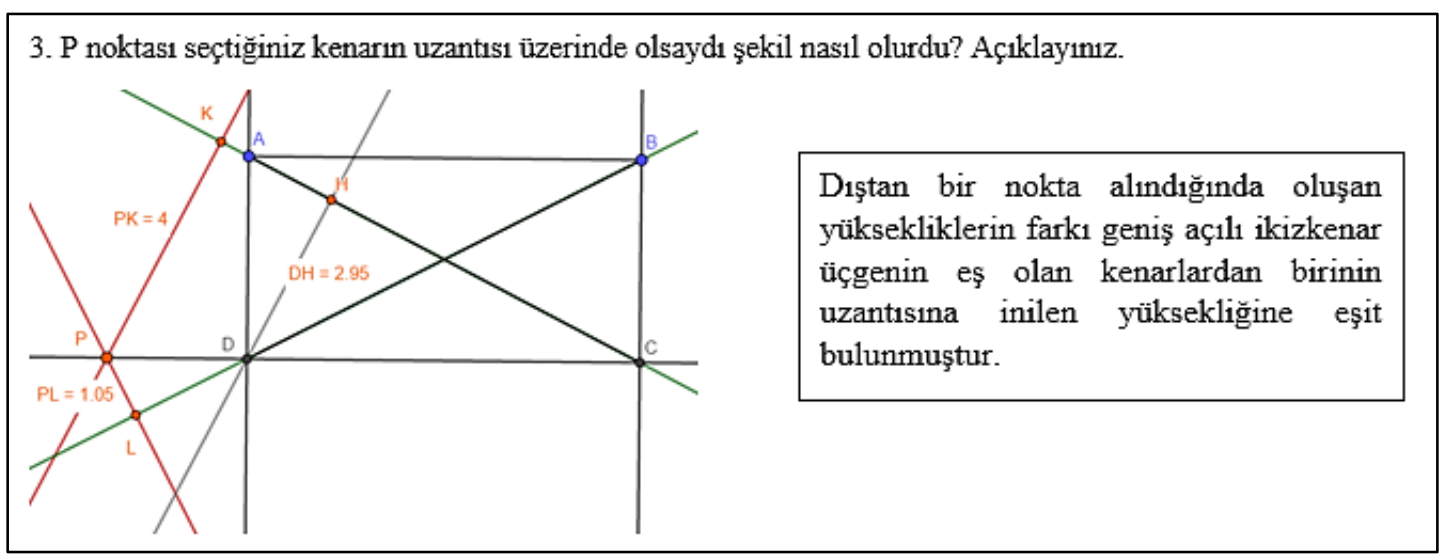

Şekil 19. Ö2 Kodlu Öğretmen Adayının 10. Probleme Verdiği Cevap

Ö2 kodlu öğretmen adayı Şekil 19'da görüldüğü gibi soruda yer alan P noktasının farklı konumuna yönelik şekli tahmin etmede, yazılımdan faydalanmıştır. Yazılım aracılığıyla çizdiği şeklin açıklamasını ise hemen yan kısımda ifade etmiştir.

\subsection{Ek Çizim Yapma Stratejisi}

$\mathrm{Bu}$ çalışmada genel olarak ek çizim yapma stratejisi tek başına problemlerin çözümünde kullanılmamıştır. Aksine birden fazla strateji ile birleşerek doğru sonuca ulaşmada söz konusu stratejilerin kullanımı etkili olmuştur. Bu duruma Ö1 kodlu öğretmen adayının Şekil 20'de yer alan probleme yönelik cevabı örnek gösterilebilir.

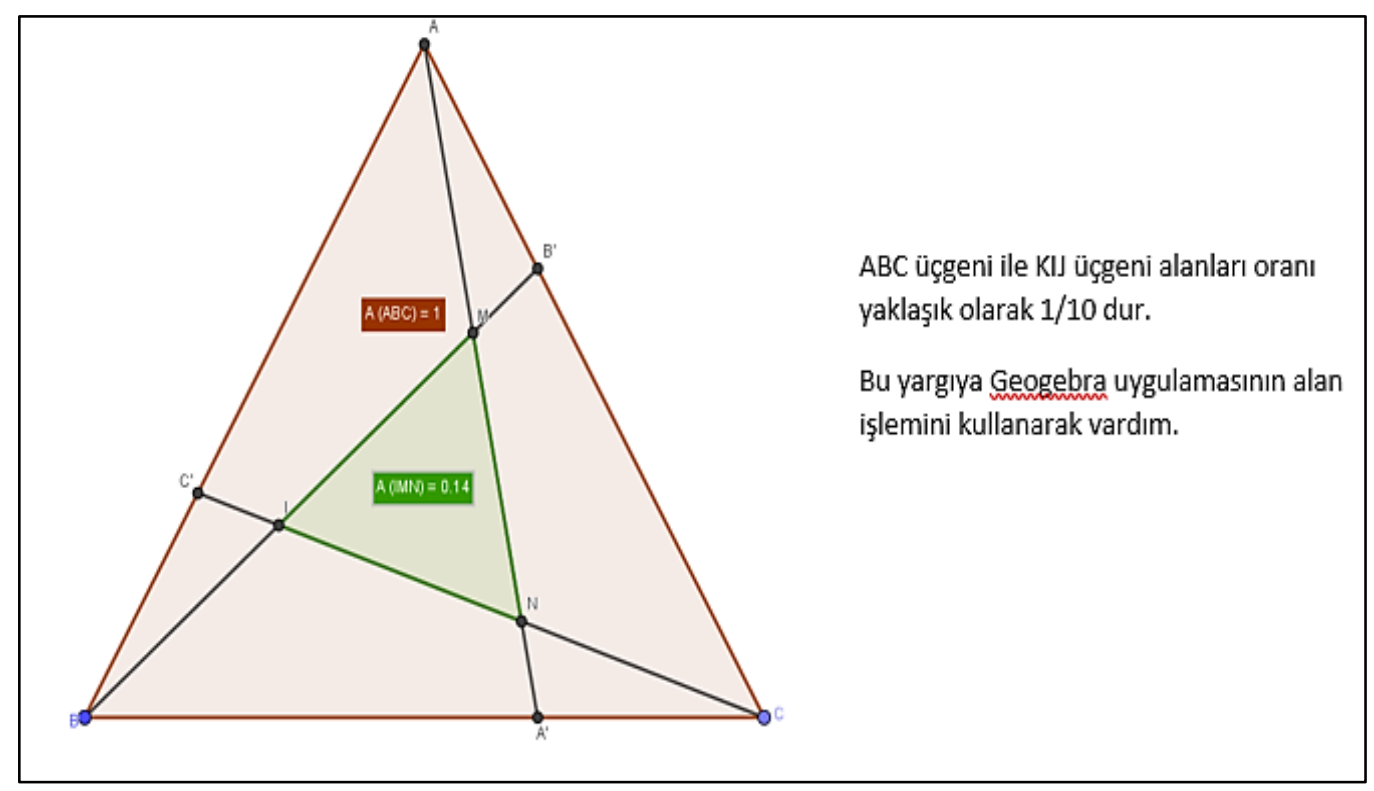

Şekil 20. Ö1 Kodlu Öğretmen Adayının Beşinci Probleme Verdiği Cevap (a)

Şekil 20incelendiğinde adayın önce verilen problemin şeklini yazılım aracılığıyla çizdiği görülmektedir. Ö1 kodlu öğretmen adayı GeoGebra'da şekli çizdikten sonra istenilen üçgenlerin alanları arasındaki oranı ise yine yazılım aracılığıyla hesaplamıştır. Dolayısıyla bu sürece öğretmen adayı problemin çözümünü matematiksel ifadelerle destekleyerek yapmadan doğru sonucu yazılım aracılığıyla öğrendiğinden tahmin etme stratejisini, GeoGebra ile problemi şekle dönüştürdüğü için de görselleştirme stratejisini kullanmıştır. Öğretmen adayı sonucu öğrendikten sonra çözüm sürecine Şekil 21'deki gibi devam etmiştir. 


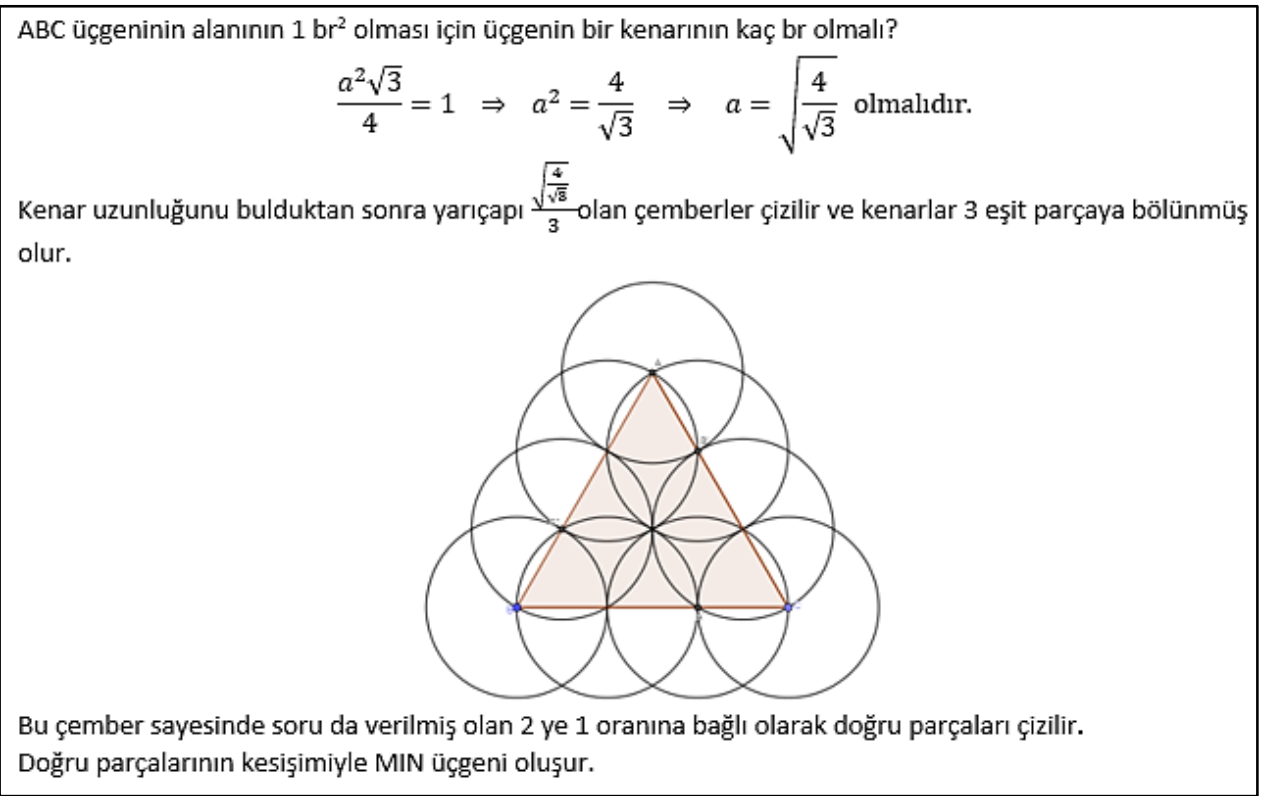

Şekil 21. Ö1 Kodlu Öğretmen Adayının Beşinci Probleme Verdiği Cevap (b)

Ö1 kodlu öğretmen adayının beşinci probleme verdiği cevabın ikinci kısmı incelendiğinde, eşkenar üçgenin kenarlarına 1 br'lik çemberler çizerek, her bir kenarı üç eşit parçaya ayırdığ 1 görülmektedir. Bu yöntem ile istenilen üçgenin bir kenar uzunluğuna ulaşarak istenilen alanı bulmuştur. Ö1 kodlu öğretmen adayı çözümün bu aşamasında çizdiği birim çemberlerden yararlanarak ek çizim yapma stratejisini kullanmıştır.

\subsection{Sürükleme Stratejisi}

Sürükleme stratejisinde, verilen bir geometrik şeklin genel yapısı değiştirmeden bazı özellikleri hareket ettirilerek doğru sonuca ulaşmayı sağlar. Şekil 22'de verilen Ö5 kodlu öğretmen adayının altıncı problemde sürükleme becerisini kullandığı görülmektedir.

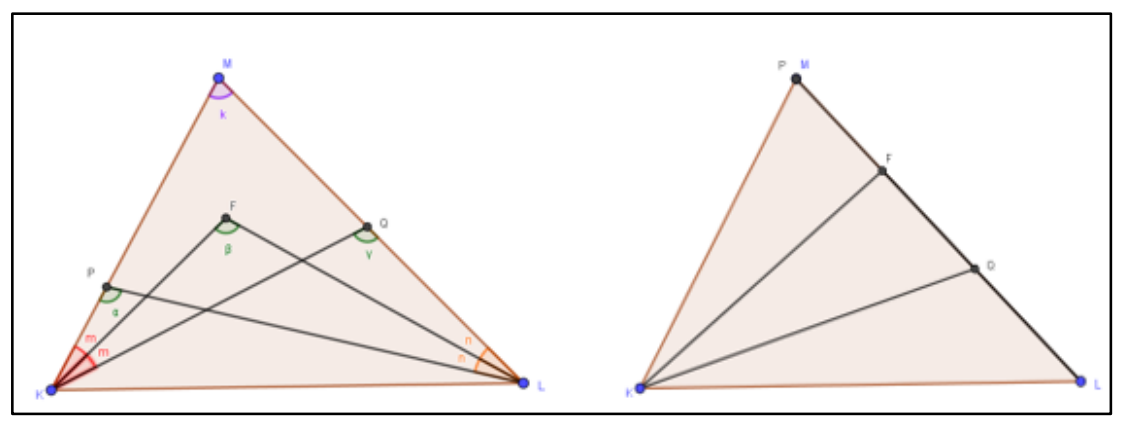

Şekil 22. Ö5 Kodlu Öğretmen Adayının Altıncı Probleme Verdiği Cevap

Şekil 22 incelendiğinde başlangıç aşamasında Ö5 kodlu öğretmen adayının (soldaki çizim) verilen problemi görselleştirdiği görülmektedir. İkinci aşamada ise (sağdaki çizim) P noktası ile $M$ noktasını sürükleyerek birbirine çakıştırdığı ve oluşan yeni şekli çizdiği görülmektedir. Ö5 kodlu aday problemde kullandığı sürükleme stratejisi sonucu oluşan yeni şeklin özelliklerini aşağıdaki şekilde tanımlamıştır:

"Şekilde $P$ ile $M$ noktasını çakıştırdığımızda, başlangıçta bulduğumuz oran aynı kalmaktadır. LP ve LM aynı doğru parçaları aynı olmuştur. $S(K P L)$ en küçük değerini almaktadır. KML ve KFL ü̧̈genlerinin bir kenarları aynı doğru parçası üzerinde olmaktadır. S(KFL) açısı ve F köşesi $M L$ doğru parçası üzerine taşınmaktadır. KFL üçgeni büyümüştür. QK sabit kalmaktadır. KML üçgeninin kenarları, köşeleri, açıları, 
alanı sabit kalmaktadır. FK doğru parçası MKQ açısının açıortayı olarak kalmaktadır."

Yukarıdaki açıklamalarından sonra Ö5 kodlu öğretmen adayı sürükleme stratejisini kullanarak yaptığı çizimi, problem çözme sürecinde aşağıdaki şekilde kullanmıştır:

"Çizdiğim şekilde $S(K P L)=S(K M L)=\alpha, \quad S(K Q L)=\gamma, \quad S(K F L)=\beta \quad$ ve $S(M K F)=S(F K Q)=m$ olarak yerleştirilmiştir. Verilen bilgilerden yararlanarak $\alpha, \beta$ ve $\gamma$ arasında bir ilişsi kurmaya çalışacă̆ız. İki iç açının toplamı bir dış açıyı verdiği için;

$$
\begin{aligned}
& \beta=\alpha+m \text { ve } \gamma=\alpha+2 m \text { olur. } \\
& \frac{\alpha+\gamma}{2}=\frac{\alpha+\alpha+2 m}{2}=\frac{2 \alpha+2 m}{2}=\frac{2(\alpha+m)}{2}=\alpha+m=\beta \text { olur. } \\
& \frac{\alpha+\gamma}{2}=\beta \text { olduğu gösterilmiş olur." }
\end{aligned}
$$

Sonuç olarak Ö5 kodlu öğretmen adayı yaptığı bu çözüm süreci ile sürükleme stratejisini kullanmıştır.

\subsection{Uç Durumları Düşünme Stratejisi}

Öğretmen adayları etkinliklerde veya son testte yer alan geometri problemlerini çözerken bazı durumlarda olabilecek uç durumları düşünmüşlerdir. Öğretmen adayları bu uç durumları düşünme stratejisini sadece son testte yer alan 10 . problemde kullanmıştır. Şekil 23 'te bu duruma örnek teşkil eden Ö3 kodlu öğretmen adayının cevabı verilmiştir.

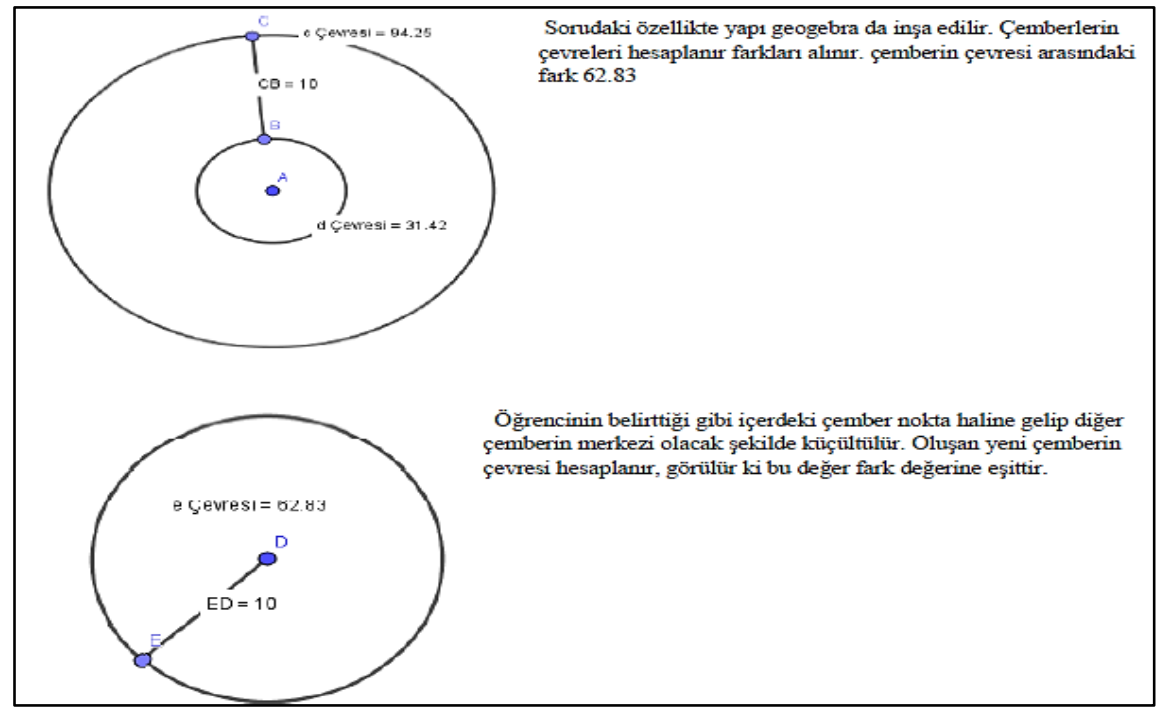

Şekil 23. Ö3 Kodlu Öğretmen Adayının Testte Yer Alan 10. Probleme Verdiği Cevap

Şekil 23 incelendiğinde Ö3 kodlu öğretmen adayının iç içe geçmiş iki çemberin çevresini hesaplarken uç durumları düşünme becerisini kullandığı görülmektedir. Yani Ö5 kodlu aday her iki çemberin çevresini bulup birbirinden çıkarmak yerine, A merkezli küçük çemberi nokta haline gelene kadar sürüklemiş ve nokta haline geldikten sonra sadece büyük çemberin kaldığını ifade etmiştir. Dolayısıyla istenen bölge sadece büyük çembere ait olduğundan, istenilen çevre uzunluğunu bulmuştur.

\subsection{Doğrulama Stratejisi}

Bazı öğretmen adayları problemleri çözerken GeoGebra yazılımını doğrulama amaçlı kullanmıştır. Bu adaylar verilen problemleri öncelikle kendileri kâğıt kalem ortamında çözmüş, daha sonra yazılım üzerinde şekil çizmiştir. En son aşamada ise istenilen uzunluk, çevre ya da alan gibi özellikler yazılım yardımıyla bakılıp sonuca ulaşılmıştır. Yazılımda yer alan sonuç ile 
kâğıt kalem üzerinde yapılan sonuç aynı ise adaylar yaptığı çözümü ispatlamış olurlar. Dolayısıyla bu bölümde yer alan strateji doğrulama stratejisi olarak kodlanmıștır. Şekil 24'te Ö14 kodlu öğretmen adayının 11. probleme verdiği cevap doğrulama stratejisinin kullanımına örnek teşkil etmektedir.

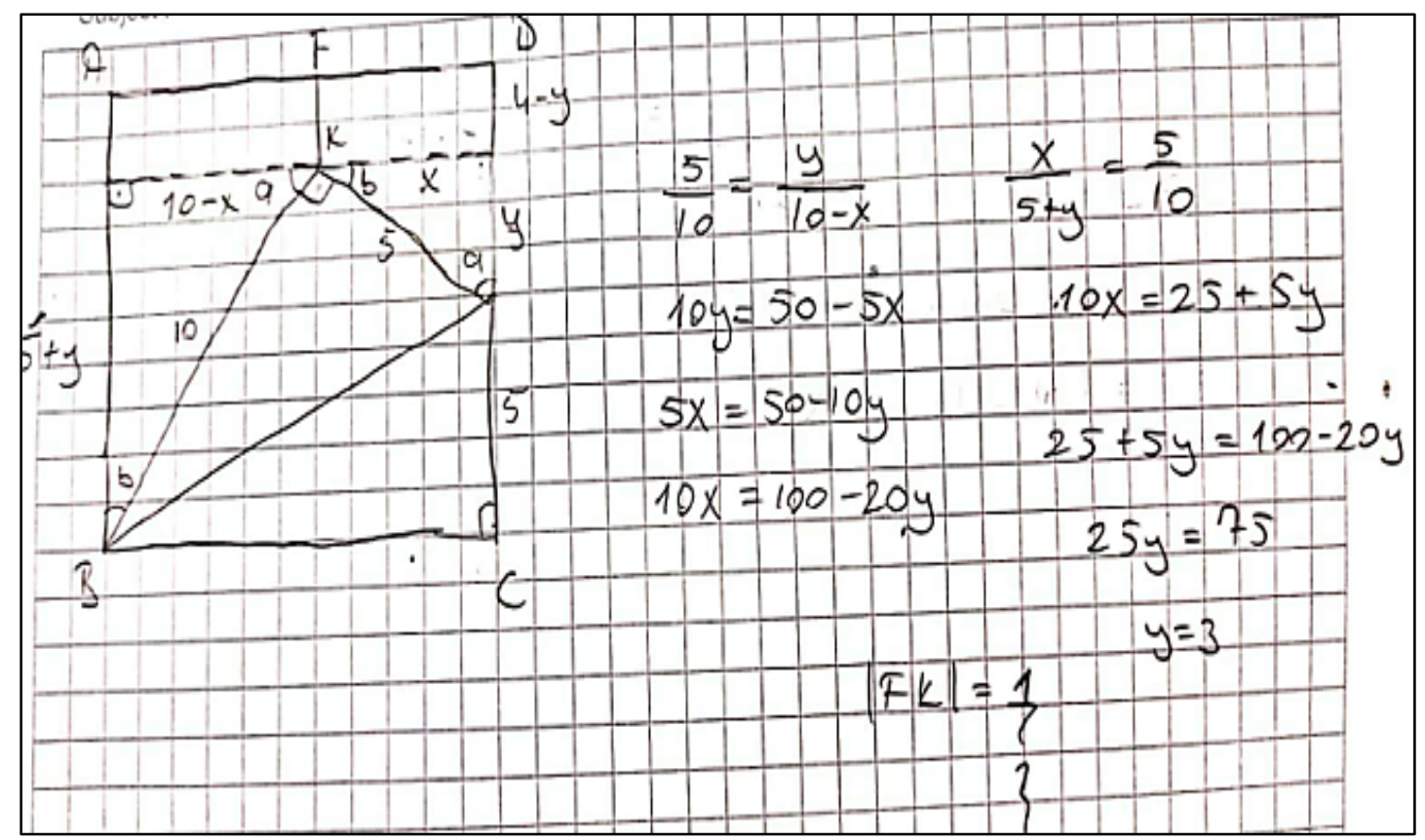

Şekil 24. Ö14 kodlu Öğretmen Adayının 11. Probleme Verdiği Cevap (a)

Şekil 24 incelendiğinde kare içerisinde yer alan katlama probleminde öğretmen adayının çözümü kâğıt kalem üzerinde yaptığı görülmektedir. Kâğıt kalem ile kenar uzunluklarını yazıp, gerekli benzerliklerden yararlandıktan sonra öğretmen adayı sonucu 1 bulmuştur. Ö14 kodlu öğretmen adayı sonucu bulduktan sonra verilen şekli yazılım üzerinde tekrar çizmiştir.

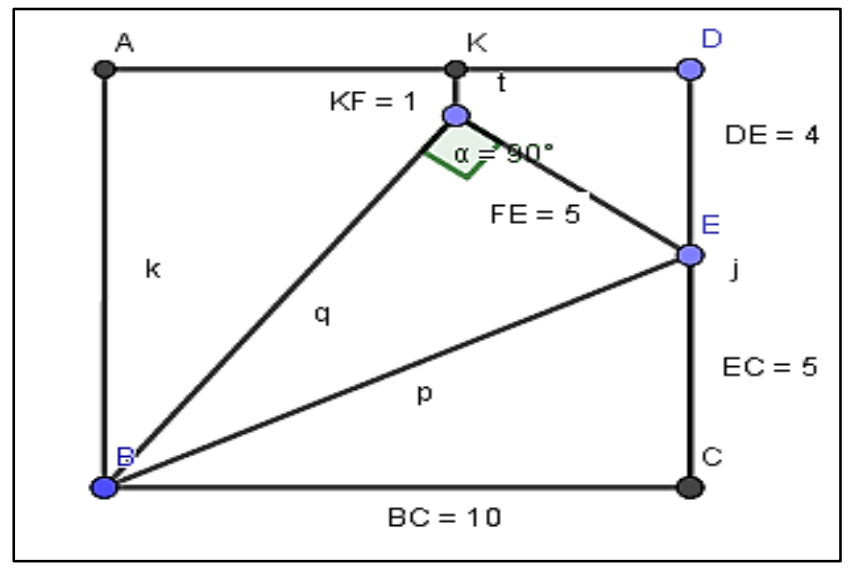

Şekil 25. Ö14 Kodlu Öğretmen Adayının 11. ProblemeVerdiği Cevap (b)

Ö14 kodlu öğretmen adayının Şekil 25’teki çiziminde de $|\mathrm{KF}|=1$ br bulduğu görülmüştür. Dolayısıyla Ö14 kodlu aday bu problemin çözümünde doğrulama stratejisini kullanmıştır.

\subsection{Tablolaştırma Stratejisi}

Öğretmen adayları bazı problemleri çözerken görselleştirme, ilişkilendirme, farklı durumları düşünme ve tablolaştırma stratejilerini aynı anda kullanmıştır. Şekil 26 'da Ö5 kodlu öğretmen adayının 10. probleme verdiği cevap bu stratejilerin kullanımına örnek oluşturmaktadır. 


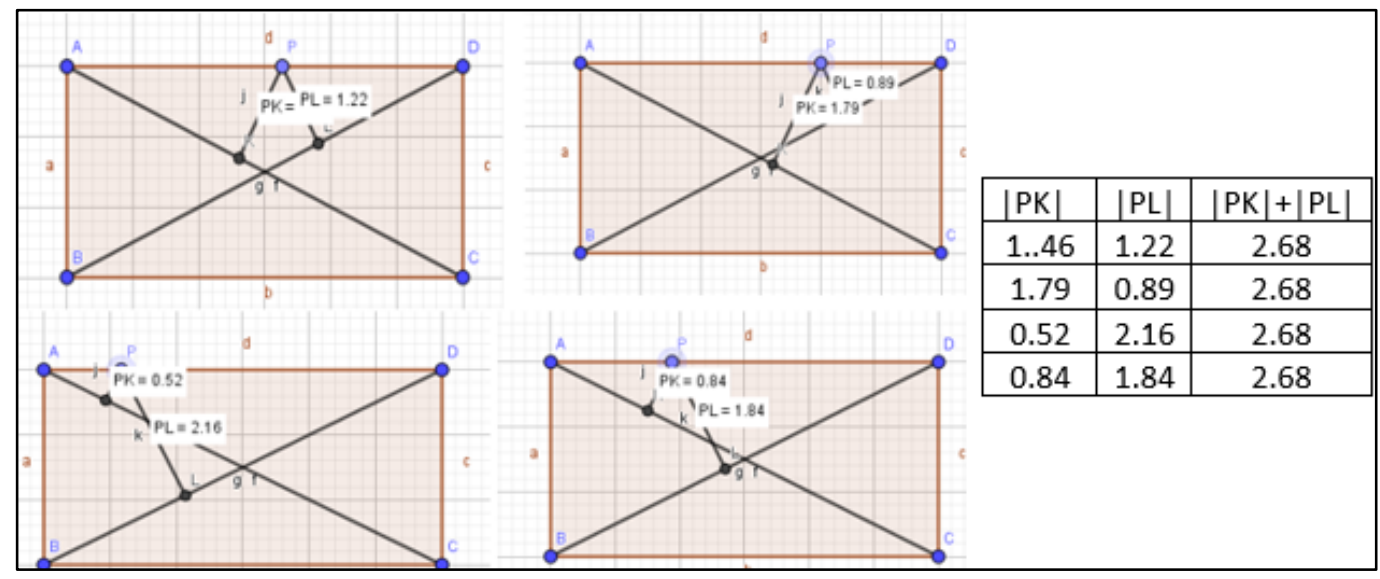

Şekil 26. Ö5 Kodlu Öğretmen Adayının 10. Probleme Verdiği Cevap

Ö5 kodlu öğretmen adayının Şekil 26'da 10. probleme verdiği cevap incelendiğinde, adayın $|\mathrm{PK}|$ ile $|\mathrm{PL}|$ uzunluklarının aldığı farklı değerlere göre dikdörtgenleri ayrı ayrı incelediği görülmektedir. Bu inceleme sonuçlarını ise Şekil 24'ün sağ tarafında yer alan tablo içerisine yazarak $|\mathrm{PK}|+|\mathrm{PL}|$ değerine bakmıştır. Ö5 kodlu öğretmen adayı bulduğu sonucu "P noktasını hareket ettirdiğimde PK+PL uzunluğu değissmemektedir. PK kisalırken PL uzamaktadır. Yinede uzunluk toplamı değişmemektedir." şeklinde ifade etmiştir. Dolayısıyla bu problemin çözümünde tablolaştırma stratejisi kullanılmıştır.

Şekil 27'de görüldüğg̈ gibi Ö3 kodlu öğretmen adayı birinci problemde yukarıdaki örneğe benzer şekilde tablolaştırma stratejisini kullanmıştır.

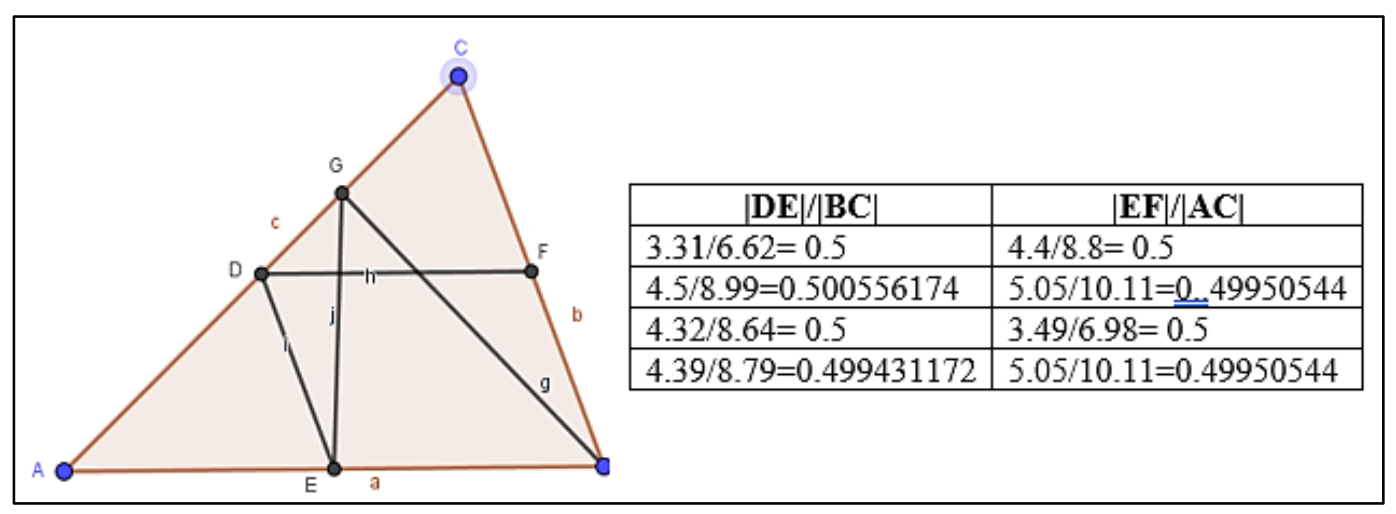

Şekil 27. Ö3 Kodlu Öğretmen Adayının Birinci Probleme Verdiği Cevap

Şekil 27 incelendiğinde Ö3 kodlu öğretmen adayının farklı kenar uzunluklarına sahip üçgenleri denediğinde (sürükleme yöntemi ile) her zaman $\frac{|D E|}{|B C|}=\frac{|E F|}{|A C|}$ ilişkisini bulduğu görülmektedir. Çözümün ilerleyen kısımlarında üçgenlerde eşlik yöntemi ile bu ilişkinin sebebini açıklayan Ö3 kodlu öğretmen adayı, problemin çözüm sürecinde görselleştirme, ilişkilendirme, farklı durumlara bakma ile tablolaştırma stratejilerini bir arada kullanmıştır.

\section{TARTIŞMA, SONUÇ VE ÖNERILER}

$\mathrm{Bu}$ çalışmada matematik öğretmeni adaylarının bilgisayar destekli ortamda geometri problem çözme stratejilerinin belirlenmesi amaçlanmıştır. Bu amaç doğrultusunda matematik ögretmen adaylarına bir dönem boyunca araştırmacılar tarafindan geliştirilen ve rutin olmayan problemler uygulanmıştır. Uygulamadan sonra ise ögretmen adaylarına "Problem Çözme Başarı 
Testi” çözdürülmüştür. Çalışmanın sonucunda öğretmen adaylarının bilgisayar destekli ortamda geometri problem çözme stratejileri; görselleştirme, döndürme, ilişkilendirme, tahmin etme, farklı durumları düşünme, ek çizim yapma, sürükleme, uç durumları düşünme, doğrulama ve tablolaştırma şeklinde belirlenmiştir.

Öğretmen adayları görselleştirme stratejisini, verilen geometri problemini görür görmez GeoGebra yazılımında şekil çizerek kullanmıştır. Adaylar ekran üzerinde çizdikleri geometrik şekli gördükten sonra farklı stratejileri de kullanarak doğru sonuca ulaşmışlardır. Bu bağlamda öğretmen adaylarının görselleştirme stratejisini kullanmalarının, problemi anlamalarında yardımcı olduğu söylenebilir. Alanyazında görselleştirmenin matematiği ve geometriyi anlamada yardımcı olduğuna dair ifadeler, çalışmadan elde edilen bu sonucu destekler niteliktedir (Duval, 1999; Lowrie ve Kay, 2001; Presmeg, 2001; Zimmermann ve Cunningham, 1991). Bu çalışmalardan biri olan Duval (1999) çalışmasında temsillerin ve görselleştirmenin matematiği anlamada önemli olduğunu vurgulamıştır. Dolayısıyla görselleştirme aracılığıyla öğrencilerin matematiği daha iyi anlayacağını savunmuştur. Bu duruma ek olarak Zimmermann ve Cunningham (1991) teknolojinin gelişimi ile görselleştirmenin daha güçlü bir araç olarak kullanılacağını ifade etmesi, bu çalışmada öğretmen adaylarının görselleştirme stratejisini GeoGebra yazılımı ile birlikte kullanmasını destekler niteliktedir. Ayrıca bu çalışmada görselleştirme stratejisini kullanan öğretmen adaylarının problem çözmede sürecinde daha iyi başarı elde ettiğine dair sonucu alanyazında görselleştirme stratejisinin öğrencilerin problem çözme başarılarını artırdığı yönünde çalışmaları destekler niteliktedir (Boyraz, 2008; İpek, 2003; Konyalığlu, 2003; Orhun, 2007).

Öğretmen adaylarının bilgisayar destekli geometri ortamlarında kullandığı stratejilerden bir diğeri de ilişkilendirme stratejisidir. Adaylar ilişkilendirme stratejisini geometrik yapıların birbiri ile ilişkisini aramada ve bu ilişkiden yararlanarak doğru sonuca ulaşmada kullanmışlardır. GeoGebra yazılımından ise geometrik yapıların kenar uzunluklarını, alanlarını hesaplayıp karşılaştırma aşamasında yararlanmışlardır. Sonuç olarak çalışmada ilişkilendirme stratejisinin aslında problem çözme süreci ile iç içe olduğu gözlenmiştir. Alanyazında da problem çözme becerisi ile ilişkilendirme stratejisinin doğrudan ya da dolaylı olarak ilişkili olduğuna dair kanıtlar araştırmadan elde edilen sonucu destekler niteliktedir (Eli, 2009; Guberman ve Leikin, 2013). Örneğin Eli (2009) problem çözmenin matematiksel ilişkilendirme için bir araç olduğunu ifade etmiştir.

Öğretmen adayları sürükleme stratejisini kullanırken, GeoGebra yazılımının makro atama, noktaları çekip bırakma, geometrik şekilleri hareket ettirme gibi özelliklerinden yararlanmışlardır. Bu aşamada dikkat çeken nokta adayların sürükleme stratejisini kullanırken geometrik yapıların değişen ve değişmeyen özelliklerini fark ettiklerinde heyecanlandıkları, öğrenme isteklerinin arttı̆̆ gözlenmiştir. Dolayısıyla sürükleme stratejisini yazılım yardımıyla kullanmanın, adayların problemleri anlamada yardımcı olduğu, başarılarını da olumlu yönde etkilediği söylenebilir. Benzer şekilde Seago vd. (2013) dinamik geometri yazılımlarının sürükleme, döndürme, öteleme gibi özellikleri matematiksel bilgilerle birlikte kullanılırsa, öğrencilerin kendi geometrilerini oluşturmalarına firsat tanınmış olacağını ifade etmiştir. $\mathrm{Bu}$ şekilde öğrenciler kavramsal boyutta geometri öğrenim sürecini yaşayacaktır. Bu öğrenme sürecini öğrencilere yaşatabilmeyi temel ilke edinen bu projenin amacı problem çözmeyi merkeze alarak hazırlanan bilgisayar destekli geometri etkinliklerinin geliştirilmesi, uygulanması ve değerlendirilmesidir.

Alanyazın incelendiğinde, öğrencilerin dinamik matematik ve geometri yazılımlarını kullanarak bazı problem çözme stratejilerinde gelişme olduğuna dair elde edilen sonuçlar bu çalışmadan elde edilen sonuçları destekler niteliktedir (Baki, Kösa ve Güven, 2011; Christou vd., 2005; Çetin, Erdoğan ve Yazlık, 2015; Kuzle, 2013; Seago vd., 2013). Bu çalışmalardan birinde Çetin, Erdoğan ve Yazlık (2015), Geogebra'nın öğrencilerin dönüşüm geometrisi konusundaki başarısına etkisine yönelik çalışmasıdır. Deneysel nitelikde yürüttüğü çalışmasının sonucunda GeoGebra yazılımı ile anlatılan dersin dönüşüm geometrisi konusunda öğrenci 
başarısını daha çok artırdığını ifade etmiştir. Çetin, Erdoğan ve Yazlık (2015) tarafindan elde edilen bu sonuç bu çalıșmada problem çözme stratejisi olarak belirlenen sürükleme stratejisinin problem çözme başarısını olumlu yönde etkilediğine dair elde edilen sonucu destekler niteliktedir. Bu durumu destekleyen bir diğer araştırma ise Baki, Kösa ve Güven (2011) tarafından yürütülen, dinamik geometri yazılımı ve fiziksel görselleştirme olarak kullanımının matematik öğretmen adaylarının uzamsal görselleştirme becerileri üzerindeki etkilerinin incelenmesine yönelik çalışmasıdır. Baki, Kösa ve Güven (2011)çalışmasının sonucunda, fiziksel manipülatiflerin ve dinamik geometri yazılımına dayalı öğretim türlerinin, öğrencilerin uzamsal görselleştirme becerilerini geliştirmede geleneksel öğretime göre daha etkili olduğunu ifade etmişledir.

$\mathrm{Bu}$ çalışmadan elde edilen diğer bir sonuç ise öğretmen adaylarının uygulama sonrasında en çok kullandığ en az kullanılan problem çözme stratejisinin ise tablolaştırma ile uç durumları düşünme stratejisi olduğunun görülmesidir. Aslında öğretmen adaylarının cevapları ayrıntılı incelendiğinde ilişkilendirme stratejisini kullanırken görselleştirme stratejisinden de yararlandıkları fark edilmiştir. Dolayısıyla problem çözerken ilişkilendirme stratejisi ile görselleştirme stratejisinin birbirini olumlu etkilediği sonucuna varılabilir. Bu durum Friel ve Markworth (2009) tarafindan yürütülen çalışmada da belirtilmiştir. Friel ve Markworth (2009) çalışmasında ilişki arama stratejisini kullanırken geometrik ve matematiksel ifadelerin görselleştirilmesinin gerekliliğini vurgulamıştır. Buna ek olarak Seago vd. (2013) geometrik nesnelerin karşılaştırılabilmesi, ilişkilendirme stratejilerinin kullanılabilmesi için öğrencilerin dönüşüm geometirisinden yararlanması gerektiğini ifade etmiştir. Dolayısıyla öğrencilerin ilişkilendirme stratejisi ile döndürme stratejilerinin iç içe olması bu çalışmadan elde edilen sonucu destekler niteliktedir.

\section{1. Öneriler}

Sonuç olarak bu çalışmada matematik öğretmeni adaylarının bilgisayar destekli ortamda geometri problem çözme stratejilerinin "görselleştirme, döndürme, ilişkilendirme, tahmin etme, farklı durumları düşünme, ek çizim yapma, sürükleme, uç durumları düşünme, doğrulama, tablolaştırma" şeklinde ortaya çıktı̆̆ 1 görülmüştür. Belirlenen bu problem çözme stratejilerine göre hazırlanan öğrenme ortamlarının, öğrencilerin problem çözme başarılarını artırabileceği düşünülmektedir. Alanyazında problem çözme başarısının akademik başarıları da olumlu etkilediğine yönelik bulgulara rastlanmaktadır (Aparı, 2019; Bayturan, 2011; Bintaş ve Bağcivan, 2007; Çetin ve Mirasyedioğlu, 2019; Genç ve Öksüz, 2016; Güven, 2012; İpek ve Malaş, 2013; Orçanlı ve Orçanlı, 2016; Roza, 2017). Dolayısıyla öğrencilerin geometri derslerindeki başarılarını artırmaya yönelik yapılacak çalışmalar için, bu çalışmadan elde edilen problem çözme stratejilerini merkeze alan öğrenme ortamları hazırlamaları önerilebilir. Yine öğrencilerin geometri problemlerini çözerken sahip olduğu problem çözme stratejileri belirlenmek isteniyorsa, bu çalışmada veri toplama aracı olarak kullanılan Problem Çözme Başarı Testi'nin uygulanması önerilmektedir. Son olarak çalışma kapsamında eğitimsel uygulamalara yapılacak bir öneri de bu çalışmada kullanılan rutin olmayan problemlerin ve Problem Çözme Başarı Testi'nde yer alan problemlerin farklı kademedeki öğrenciler üzerinde uygulanabilmesidir. Ön test son test kontrol ve deney grubu ile farklı kademedeki öğrencilerle çalışılarak eğitimsel sonuçlar irdelenebilir.

\section{KAYNAKÇA}

Açıkgül, K., \& Aslaner, R. (2014). Bilgisayar destekli öğretim ve matematik öğretmen adayları: Bir literatür incelemesi. İnönü Üniversitesi Eğitim Bilimleri Enstitüsü Dergisi, 1(1), 4151. 
Açıkgül, K. (2012). Öğretmen adaylarının dinamik geometri yazılımı kullanarak geometrik yer problemlerini çözüm süreçlerinin ve bu süreçlere ilişkin görüşlerinin incelenmesi. (Yayınlanmamış Yüksek Lisans Tezi). İnönü Üniversitesi Eğitim Bilimleri Enstitüsü. Malatya.

Aparı, B. (2019). Geogebra destekli problem kurma temelli ögrenme sürecinin ögrencilerin problem kurma becerisine ve öz yeterlik inancına etkisi. (Yayınlanmamış Yüksek Lisans Tezi). Dicle Üniversitesi Eğitim Bilimleri Enstitüsü. Diyarbakır.

Baki, A. (2002). Öğrenen ve öğretenler için bilgisayar destekli matematik. İstanbul: Ceren Yayın Dă̆ıtım.

Baki, A. (2008). Kuramdan uygulamaya matematik eğitimi (4. Baskı). Ankara: Harf.

Baki, A., Kösa, T., \& Güven, B. (2011). A comparative study of the effects of using dynamic geometry software and physical manipulatives on the spatial visualisation skills of preservice mathematics teachers. British Journal of Educational Technology, 42(2), 291-310.

Bayturan, S. (2011). Ortaöğretim matematik eğitiminde bilgisayar destekli öğretimin, ögrencilerin başarıları, tutumları ve bilgisayar öz-yeterlik algıları üzerindeki etkisi. (Yayınlanmamış Doktora Tezi). Dokuz Eylül Üniversitesi Eğitim Bilimleri Enstitüsü. İzmir.

Bintaş, J., \& Akıll1, B. (2008). Bilgisayar destekli geometri. Ankara: Pegem Akademi.

Bintaş, J., \& Bağcivan, B. (2007). İlköğretim yedinci sınıfta bilgisayar destekli geometri öğretimi. Hasan Ali Yücel Ĕgitim Fakültesi Dergisi, 7, 33-45.

Bond, T. G., \& Fox, C. M. (2013). Applying the Rasch model: Fundamental measurement in the human sciences. Psychology Press.

Boyraz, Ş. (2008). Bilgisayar destekli öğretimin yedinci sınıf ögrencilerin uzamsal düşünebilme becerilerine, matematik, teknoloji ve geometriye karşı tutumlarına etkisi. (Yayınlanmamış Yüksek Lisans Tezi). Orta Doğu Teknik Üniversitesi Sosyal Bilimler Enstitüsü. Ankara.

Bulut, S., Ekici, C., İşeri, A. İ., \& Helvacı, E. Geometriye yönelik bir tutum ölçeği. Eğitim ve Bilim, 27(125), 3-7.

Bülbül, B. Ö., Güler, M., Gürsoy, K., \& Güven, B. (2020). For what purpose do the student teachers use DGS? A qualitative study on the case of continuity. International Online Journal of Education and Teaching (IOJET), 7(3). 785-801.

Bülbül, B.Ö. (2021, Şubat). Developing, implementing and evaluating the effects of computer aided geometry activities for pre-service mathematics teachers' problem solving skills [National Project].Manisa Celal Bayar University.

Christou, C., Mousolides, N., Pittalis, M., \& Pitta-Pantazi, D. (2005). Problem solving and problem posing in a dynamic geometry environment. The Montana Mathematics Enthusiast, 2(2), 125-143.

Cohen, L., \& Manion, L. (1994). Research methods in education (Fourth Edition). London: Routledge.

Çepni, S. (2001). Araştırma ve proje çalışmalarına giriş. Trabzon: Erol Ofset Matbaacılık.

Çetin, İ., Erdoğan, A., \& Yazlık, D. Ö. (2015). Geogebra ile öğretimin sekizinci sınıf öğrencilerinin dönüşüm geometrisi konusundaki başarılarına etkisi. Uluslararası Türk Ĕ̈itim Bilimleri Dergisi, 2015(4), 84-92.

Çetin, Y., \& Mirasyedioğlu, Ş. (2019). Teknoloji destekli probleme dayalı öğretim uygulamalarının matematik başarısına etkisi. Journal of Computer and Education Research, 7(13), 13-34. 
Diego-Mas, J. A., Santamarina-Siurana, M. N., Alcaide-Marzal, J., \& Cloquell-Ballester, V. A. (2009). Solving facilitry layout problems with strict geometric constraints using a twophase genetic algorithm. International Journal of Production Research, 47(6), 16791693.

Duval, R. (1999). Representation, vision, and visualization: Cognitive functions in mathematical thinking. Basic Issues For Learning. Paper presented at the Proceedings of the Annual Meeting of the North American Chapter of the International Group for the Psychology of Mathematics Education, Morelos, Mexico. (ERIC Document Reproduction Service No. ED 466379).

Eli, J. A. (2009). An exploratory mixed methods study of prospective middle grades teachers' mathematical connections while completing investiagtive tasks in geometry. (Unpublished Doctoral Dissertation). University of Kentucky, USA.

Ertem-Akbaş, E., \& Baki, A. (2020). MYO öğrencilerinin bilgisayar destekli ortamda "limitsüreklilik" konusundaki öğrenmelerinin SOLO taksonomisine göre değerlendirilmesi: Bir eylem araştırması. Journal of Compute rand Education Research, 8(16), 631-671. http://doi.org/10.18009/743769.

Fan, L., Qi, C., Liu, X., Wang, Y., \& Lin, M. (2017). Does a transformation approach improve students's ability in constructing auxiliary lines for solving geometric problems? An intervention-based study with two Chinese classrooms. Educational Studies in Mathematics, 96, 229-248.

Fisher, B. L., Allen, R., \& Kose, G. (1996). The relationship between anxiety and problemsolving skills in children with and without learning disabilities. Journal of Learning Disabilities, 29(4), 439-446.

Friel, S. N., \& Markworth, A. (2009). A framework for analyzing geometric pattern tasks. Mathematics Teaching in Middle School, 15(1), 24-33.

Genç, G., \& Öksüz, C. (2016). Dinamik matematik yazılımı ile 5. sınıf çokgenler ve dörtgenler konularının öğretilmesi. Kastamonu Eğitim Dergisi, 24(3), 1551 - 1566.

González, G., \& Herbst, P. G. (2009). Students' conceptions of congruency through the use of dynamic geometry software. International Journal of Computers for Mathematical Learning, 14, 153-182.

Guberman, R., \& Leikin, R., (2013). Interesting and difficult mathematical problems: Changing teachers' views by employing multiple-solution tasks. Journal of Mathematics Teacher Education, 16(1), 33-56. http://doi.org/10.1007/s10857-012-9210-7.

Güven, B. (2012). Using dynamic geometry software to improve eight grade students' understanding of transformation geometry. Australasian Journal of Educational Technology. 28(2), 364-382.

Güven, B., \& Karataş, İ. (2003). Dinamik geometri yazılımı Cabri ile geometri öğrenme: Öğrenci görüşleri. The Turkish Online Journal of Educational Technology, 2(2), 67-78.

Hangül, T., \& Üzel, D. (2010). Bilgisayar destekli öğretimin (BDÖ) 8. sınıf matematik öğretiminde öğrenci tutumuna etkisi ve BDÖ hakkında öğrenci görüşleri. Necatibey Eğitim Fakültesi Elektronik Fen ve Matematik Eğitimi Dergisi, 4(2), 154-176.

Hoffman, B., \& Schraw, G. (2009). The influence of self-efficacy and workingmemory capacity on problem-solving efficiency. Journal of Learning and Individual Differences, 19(1), 91-100. 
İpek, A. S. (2003). Kompleks sayılarla ilgili kavramların anlaşılmasında görselleştirme yaklaşımının etkinliğinin incelenmesi. (Yayınlanmamış Doktora Tezi). Atatürk Üniversitesi Fen Bilimleri Enstitüsü. Erzurum.

İpek, J. \& Malaş, H. (2013). Bilgisayar destekli matematik dersinde star stratejisinin ilköğretim 2. sınıf öğrencilerinin matematik dersi başarıları ve problem çözme becerileri üzerindeki etkisi. Necatibey Eğitim Fakültesi Elektronik Fen ve Matematik Eğitimi Dergisi, 7(2), 314-345.

Kaur, B., Har, Y. B., \& Kapur, M. (2009). Mathematical Problem Solving Association of Mathematics Educators. Singapore.

Kawabata, R., \& Itoh, K. (2009). Computer-aided solid geometry learning (CASGL). Society for Design and Process Science Printed in the United States of America., 13(4), 19-34.

Kertil, M. (2020). Covariational reasoning of prospective mathematics teachers: How do dynamic animations affect?. Turkish Journal of Computer and Mathematics Education, $11(2), 312-342$.

Konyalığlu, A. C. (2003). Üniversite düzeyinde vektör uzayları konusundaki kavramların anlaşılmasında görselleştirme yaklaşımının etkinliğinin incelenmesi. (Yayınlanmamış Doktora Tezi). Atatürk Üniversitesi Fen Bilimleri Enstıtüsü. Erzurum.

Kuzle, A. (2013). Patterns of metacognitive behavior during mathematics problem-solving in a dynamic geometry environment. International Electronic Journal of Mathematics Education, 8(1), 20-40.

Lester, F. K. (1994). Musings about mathematical problem solving research: 1970-1994. Journal for Research in Mathematics Education, 25(6), 660-675.

Lowrie, K. (2001). Relationship between visual and non visualsolution methods and difficulty in elementary mathematics. The Journal of Educational Research, 94(4), 248-255.

Milli Eğitim Bakanlığı [MEB]. (2018). Illkokul ve ortaokul 1,2,3,4,5,6,7 ve 8. sinıflar için matematik dersi ögretim programı. Ankara: Millî Eğitim Bakanlığı Yayınevi.

Miles, M. B., \& Huberman, A. M. (1994). Qualitative data analysis: An expanded sourcebook (2nd Edition). Arizona: Sage Publications, Inc.

National Council of Teachers of Mathematics [NCTM]. (2000). Let's count in curriculum and evaluation standards for school mathematics. VA: Retson.

Novita, R., Zulkardi, Z., \& Hartono, Y. (2014). Exploring primary student's problem-solving ability by doing tasks like PISA's question. Journal on Mathematics Education, 3(2), 133-150.

Orçanlı, H. B., \& Orçanlı, K. (2016). Bilgisayar destekli geometri öğretiminin 7. sınıf öğrencilerinin geometri başarısına ve geometri özyeterlik algısına etkisi. Social Sciences Research Journal, 5(1), 80-97.

Orhun, N. (2007). Kesir işlemlerinde formal aritmetik ve görselleştirme arasındaki bilişsel boşluk. İönü Üniversitesi Eğitim Fakültesi Dergisi. 8(14), 99-111.

Özdemir, F., Aslaner, R., \& Açıkgül, K. (2020). The effect of the computer-aided mathematics teaching on students' attitudes towards mathematics: A meta-analysis study. Inönü University Journal of the Graduate School of Education, 7(13), 20-40.

Palinkas, L. A., Horwitz, S. M., Green, C. A., Wisdom, J. P., Duan, N., \& Hoagwood, K. (2015). Purposeful sampling for qualitative data collection and analysis in mixed method implementation research. Administration and policy in mental health and mental health services research, 42(5), 533-544. 
Polya, G. (1990). How to solve it?. (Çev. F. Halatç1). New York.

Presmeg, N. C., \& Balderas-Cañas, P. E. (2001). Visualization and affect in nonroutine problem solving. Mathematical Thinking and Learning, 3(4), 289-313.

Roza, Y. (2017). Computer-based media for learning geometry at mathematics class of secondary schools. Journal of Educational Sciences, 1(1), 79-91.

Santos-Trigo, M., \& Espinosa-Pérez, H. (2010). High school teachers use of dynamic software to generate serendipitous mathematical relations. The Mathematics Enthusiast, 7(1), 3146.

Schoenfeld, A. H. (1992). Learning to think mathematically: Problem solving, metacognition and sense making in mathematics. In D. A. Grouws (Ed.), Handbook Of Research On Mathematics Teaching (pp. 334-370 ). New York: MacMillan Publishing.

Seago, N., Jacobs, K. J., Dricsoll, M., Nikula, J., Matassa, M., \& Callahan, P. (2013). Developing teachers' knowledge of a transformations-based approach to geometric similarity. Mathematics Teacher Educator, 2(1), 74-85.

Surya, E., Andriana, F., \& Mukhtar, P. (2017). Improving mathematıcal problem solving ability and self-confidence of high school students through contextual learning model. Journal on Mathematics Education, 8(1), 85-94.

Tapan-Broutin, M. S. (2010). Bilgisayar etkileşimli geometri ögretimi. İstanbul: Ezgi Kitabevi.

Wong, W. K., Yin, S. K., Yang, H. H. \& Cheng, Y. H. (2011). Using computer-asisted multiple representation in learning geometry proofs. Educational Technology \& Society, 14(3), 4354.

Yemen, S. (2009). Illköğretim 8. sinıf analitik geometri öğretiminde teknoloji destekli öğretimin ögrencilerin başarısına ve tutumuna etkisi. (Yayınlanmamış Yüksek Lisans Tezi). Dokuz Eylül Üniversitesi Eğitim Bilimleri Enstitüsü. İzmir.

Zengin, A., \& Akçakın, V. (2021). The effect of GeoGebra assisted mathematics teaching on the achievements of sixth grade students: Area and volüme measurement. SDU International Journal of Educational Studies, 8(1), 51- 67. http://doi.org/10.33710/sduijes.871299.

Zimmermann, W., \& Cunningham, S. (1991). Editor's introduction: What is mathematical visualization. In W. Zimmermann, \& S. Cunningham (Eds.), Visualization in Teaching And Learning Mathematics (pp. 1-8). Washington, DC: Mathematical Association of America.

\section{EXTENDED ABSTRACT}

Geometry can be seen by students as a difficult course to understand. One of the main reasons for this situation is that students try to transfer some formulas to the shape by rote. This difficulty can be overcome by creating problem-solving-centered geometry course content (National Council of Teachers of Mathematics [NCTM], 2000).

As Wong, Yin, Yang and Cheng (2011) state, for an efficient process of geometry problem-solving, the pencil-paper process and the process of creating the geometric structure in dynamic geometry software should be intertwined. Students should use dynamic geometry software not only for visualization or conclusion purposes but to investigate the reason behind the solution of the problem. Therefore, the fact that the literature has not focused on the use of dynamic geometry software as a teaching tool in determining students' problem-solving strategies constitutes the importance of this study. In this study, geometry activities centered on problem-solving strategies were applied to pre-service mathematics teachers for one semester 
using GeoGebra, one of the dynamic geometry software. Therefore, this study aims to determine on problem solving strategies of pre-service mathematics teachers in a computer aided environment

This study, in which the case study method was used, was carried out with 14 pre-service teachers studying in the second grade of the Primary Education Mathematics Education program in the Fall Semester of the 2020-2021 Academic Year at a state university. Also, the "Problem Solving Achievement Test" was administered to pre-service teachers after a semesterlong practice. Clinical interviews were conducted with six pre-service teachers who were selected among 14 pre-service teachers who participated in the application. While the preservice teachers were selected, they were categorized as high, medium, and low levels according to the problem-solving strategies they used. Two students were chosen from each level. Problem Solving Achievement Test, non-routine problems, researcher field notes, and clinical interviews were used as data collection tools of the study. Bülbül (2021) analyzed the validity and reliability of the problem-solving achievement test and found the reliability coefficient of the problem-solving success test as .69 and the item reliability indicator as .82. In order to ensure the validity of the achievement test, expert opinions consulted whether the problems in the measurement tool are suitable for the purpose of measurement and whether they represent the area to be measured.

Non-routine problems were previously developed by researchers within the scope of a project (Bülbül, 2021). After the validity and reliability of the activities were provided by the researchers, a total of 15 different non-routine problems were applied to pre-service mathematics teachers. Non-routine problems covers a variety of subjects such as triangle similarity, triangle congruence, triangle inequality, median properties, triangle area, Menalous Theorem, Seva Theorem, angles in the triangle, bisector and its properties, height and properties, quadrilateral and its properties, circle and its properties, the inner tangent circle of a triangle, and circumferential circle applications.

Due to the COVID-19 pandemic process, "Computer-Assisted Mathematics Education" courses in the context of this study were conducted for 13 weeks in an online learning environment using the Microsoft Teams platform. The advantages of this platform include screen sharing, the ability to see each candidate's solution at the time, and the ability of the teacher candidates to speak comfortably whenever they want. Since pre-service teachers do not have to open a camera during the lesson, their ability to express themselves more comfortably, and the ability to take notes by watching the incomprehensible parts from the recording after the lesson has been an advantage in terms of reliability of the data.

In the study, weekly responses of the pre-service mathematics teachers to non-routine problems and responses to the "Problem Solving Achievement Test" were subjected to content analysis by the researchers. As a result of the content analysis, the problem solving strategies used by the pre-service teachers who took part in the achievement test and problems were coded separately by the researchers. Then, the internal validity and reliability were obtained by calculating the inter-coder reliability percentage. Regarding, codes based on the problemsolving strategies of the participants were examined. The reliability of the analysis conducted by the researchers was calculated using the formula Number of Agreements ( Number of Agreements + Number of Disagreements)
inter-coder reliability percentage of the analysis performed through the scoring system was calculated as $94 \%$.

As a result of the study, the problem-solving strategies of the pre-service mathematics teachers were determined as "visualization, rotation, relationship between geometric figures, guessing, looking at different situations, making additional drawing, dragging, thinking extreme situations, justifying and tabulation" solving computer-assisted geometry problems developed by focusing problem-solving strategies. Examples of these strategies are included in the study. 
Another result obtained from this study is that the most frequently used problem-solving strategies by pre-service teachers after the application is to relationship between geometric figures, and the least used problem-solving skill is to tabulation and think extreme situations. When the answers of the pre-service teachers were examined in detail, it was noticed that they also benefited from the visualization strategy while using the are relationship between geometric figure strategy. Therefore, it can be concluded that the relationship between geometric figure strategy and the visualization strategy affect each other positively while solving problems. The same situation was stated in the study conducted by Friel and Markworth (2009). Friel and Markworth (2009) emphasized the need to visualize geometric and mathematical expressions when using the associating strategy.

In the light of the results obtained from the study, preparing learning environments centered on problem-solving strategies is recommended for future studies on increasing students' success in geometry lessons. In studies aimed at determining the problem-solving strategies used by pre-service teachers while solving geometry problems, it is recommended to apply the "Problem Solving Achievement Test", which was used as a data collection tool in this study. Finally, applying the non-routine problems and the "Problem Solving Achievement Test" to students at different levels is recommended for educational applications. Therefore, educational results can be examined by studying with students at different levels with the pretest, post-test control, and experimental groups. 